\title{
MATERIALS FOR THE STUDY OF ITEMS FROM NON-FERROUS AND PRECIOUS METALS OF SELITRENNOE SETTLEMENT: CHEMICAL COMPOSITION
}

\author{
Kseniya S. Kovaleva \\ Institute of Archaeology RAS, Moscow, Russian Federation; \\ Volgograd State University, Volgograd, Russian Federation
}

\begin{abstract}
Absract. Introduction. This paper presents the results of the study of the chemical composition of nonferrous and precious metal items from the excavations of the Selitrennoe settlement by the Volga Region Archaeological Expedition in 1986-1989 stored in the State Historical Museum. Methods and materials. XRF was used as a method of determining the elemental composition; the main technological operations were determined using the trasology method. A total of 63 subjects were analyzed, including domestic items, jewelry and items related to production. Analysis and Results. The alloys have been distinguished depending on the presence and concentration of alloying elements: brass (two-component, tin, lead, multicomponent), bronzes (tin, lead, leadarsenic, tin-lead, tin-zinc, and multicomponent) and silver alloys (multicomponent high silver bronzes and goldsilver alloy). Inclusions of soldering with silver in the solder and gilding according to the amalgamation have been also recorded. The results of the analysis show the prevalence of two-component brass and multicomponent alloys, a small amount of tin bronzes and the complete absence of items from "pure" metals - copper, tin and lead. The common practice of using recycled metal can be judged by the relatively low content of zinc in brass and a large proportion of multicomponent alloys. Despite the presence of distinguishable stable groups, a wide range of concentrations suggests the absence of clear recipes, including for certain categories of objects. The dependence of the applied technology on the composition of metal is also revealed. The sample of the Selitrennoe settlement is significantly different from other large series of analyses of the Golden Horde time (Bolgar Region, Uvek and its neighborhood).
\end{abstract}

Key words: Golden Horde, Selitrennoe settlement, metalworking, chemical composition, XRF analysis.

Citation. Kovaleva K.S. Materials for the Study of Items from Non-Ferrous and Precious Metals of Selitrennoe Settlement: Chemical Composition. Vestnik Volgogradskogo gosudarstvennogo universiteta. Seriya 4. Istoriya. Regionovedenie. Mezhdunarodnye otnosheniya [Science Journal of Volgograd State University. History. Area Studies. International Relations], 2020, vol. 25, no. 4, pp. 328-347. (in Russian). DOI: https://doi.org/10.15688/ jvolsu4.2020.4.22

\section{МАТЕРИАЛЫ К ИЗУЧЕНИЮ ИЗДЕЛИЙ ИЗ ЦВЕТНЫХ И ДРАГОЦЕННЫХ МЕТАЛЛОВ СЕЛИТРЕННОГО ГОРОДИЩА: ХИМИЧЕСКИЙ СОСТАВ}

\section{Ксения Сергеевна Ковалева}

Институт археологии РАН, г. Москва, Российская Федерация; Волгоградский государственный университет, г. Волгоград, Российская Федерация

Аннотация. В статье опубликованы результаты исследования химического состава предметов из цветных и драгоценных металлов из раскопок Селитренного городища 1986-1989 гг, хранящихся в фондах Государствен- 
ного исторического музея. В работе использовался метод рентгенофлюоресцентной спектрометрии и визуальный анализ поверхностей изделий. Всего было проанализировано 63 предмета, среди которых бытовые вещи, украшения и предметы, связанные с производством. В результате были выявлены сплавы латуни (двухкомпонентная, оловянная, свинцовая, многокомпонентная), бронзы (оловянная, свинцовая, свинцово-мышьяковистая, оловянно-свинцовая, оловянно-цинковая, многокомпонентная) и сплавы с серебром (многокомпонентные бронзы с повышенным содержанием серебра и золото-серебряный сплав). Зафиксированы также пайка с серебром в составе припоя и золочение по методу амальгирования. Установлено доминирование двойных латуней и многокомпонентных сплавов, небольшое количество оловянных бронз и полное отсутствие изделий из «чистых» металлов - меди, олова и свинца. Подтверждена распространенная практика использования вторичного металла. Несмотря на выявленные устойчивые группы сплавов, широкий разброс концентраций позволяет предполагать отсутствие четких рецептур, в том числе для отдельных категорий вещей. При этом прослеживается зависимость применяемой технологии от состава металла. Полученные данные указывают на специфические особенности ремесленного производства Селитренного городища в сравнении с другими изученными центрами золотоордынского времени (Болгарский улус, Увек и его округа).

Ключевые слова: Золотая Орда, Селитренное городище, металлообработка, химический состав, рентгенофлюоресцентный анализ.

Цитирование. Ковалева К. С. Материалы к изучению изделий из цветных и драгоценных металлов Селитренного городища: химический состав // Вестник Волгоградского государственного университета. Серия 4, История. Регионоведение. Международные отношения. - 2020. - Т. 25, № 4. - C. 328-347. - DOI: https:// doi.org/10.15688/jvolsu4.2020.4.22

Введение. Расположенное в современной Астраханской области на левом берегу p. Ахтубы Селитренное городище является остатками одного из крупнейших городов Золотой Орды и ее вероятной столицей. В 1965-1995 гг. здесь работала Поволжская археологическая экспедиция под руководством Г.А. Федорова-Давыдова, вскрывшая более 20 тыс. кв. м памятника [19, с. 26]. Полученная в ходе раскопок коллекция предметов хранится в фондах Государственного исторического музея ${ }^{1}$.

Одним из параметров, характеризующих особенности средневекового ремесленного производства, является химический состав металла [11, с. 203]. Цветной металл Золотой Орды и, в частности, элементный состав изделий, уже неоднократно привлекал внимание исследователей. Так, Т.А. Хлебниковой был проанализирован химический состав более 80 предметов из цветного металла доордынского и золотоордынского Болгара и Биляра [20]; С.И. Валлиулиной - золотоордынские материалы Торецкого селища округи Биляра (18 проб) [2]; И.Е. Зайцева дополнила эти материалы данными еще для 376 образцов, из которых 124 относятся к золотоордынскому времени [7]. Для Саратовского Поволжья была проведена масштабная работа по изучению цветного металла Л.Ф. Недашковским, опубликовавшим результаты анализов 225 предметов, происходя- щих с из коллекции Увекского городища и селищ его округи [12; 13]. Введена в научный оборот небольшая серия анализов (19 предметов) для Царевского городища и близлежащих синхронных ему могильников [10]. Данная статья продолжает работы по изучению изделий из цветных металлов городов Золотой Орды. Целью работы является исследование элементного состава изделий из цветных и драгоценных металлов, происходящих с Селитренного городища, которые должны пополнить существующую базу данных по химическому составу металла золотоордынского времени.

Методы и материалы. В работе использовался рентгенофлюоресцентный анализ (РФА), основанный на возбуждающем элементы рентгеновском излучении и последующем измерении величин их аналитических сигналов [5, с. 143-144]. Этот способ имеет свои особенности и ограничения: поверхностный характер анализа, сильное влияние на результат имеющихся на предмете коррозионных наслоений, сложности рельефа и т. д. Но, несмотря на это, на данный момент РФА-спектрометрия является одним из самых распространенных и эффективных методов исследования химического состава археологического металла [5, с. $144-145 ; 11$, с. 204,$216 ; 18$; 21, pp. 237-238; 22, pp. 42-51; и др.].

Работа выполнена на базе отдела археологических памятников Государственного 


\section{СИМВОЛИЗМ И ТЕХНОЛОГИИ В МАТЕРИАЛЬНОЙ КУЛЬТУРЕ}

исторического музея на РФА-анализаторе Bruker Mistral M1 2. Объем исследуемой выборки составил 63 изделия, для каждого предмета было получено по 2-3 пробы, данные представлены в виде среднего значения (табл. 1). Также проведен визуальный осмотр вещей по установленной методике [3] при помощи цифрового микроскопа AxioCam ERc 5s. Все анализируемые вещи происходят из раскопок Селитренного городища 1986-1989 гг., из слоев XIV в. [19, с. 26] (раскопы XI, XIII, XV, XVI, XVII, XVIII); больше половины являются подъемным материалом и не имеют археологического контекста. В целом, коллекция датируется XIV веком.

Анализ. Для обработки результатов спектрального анализа была использована классификация металлов и сплавов на основе меди, предложенная Н.В. Ениосовой, Р.А. Митоян и Т.Г. Сарачевой [6, с. 131].

Большинство изделий оказались выполненными из сплавов на основе меди, небольшая группа изделий (3 экз.) была изготовлена из золото-серебряного сплава (табл. 2 и рисунок).

Сплавы на основе меди представлены латунями и бронзами; их более дробное деление зависит от наличия легирующих компонентов и их концентрации. Пороговое значение для определения искусственных лигатур традиционно определено от 1,0 \%.

Латунь - сплав на основе меди, основным легирующим компонентом в котором является цинк; пластичный, легко поддающийся обработке в холодном и горячем состояниях металл, пригодный к сварке и лужению $[15$, c. 39]. Из двухкомпонентной латуни изготовлено 12 изделий (19\%), среди которых пинцет, подвеска, поясные бляхи с золочением и серебрением, черпак ложки, щитки перстней, сюльгама, бубенчик и изделие неизвестного назначения в виде полусферы. Содержание латуни в них колеблется от 1,3 до 19,4 \%, среднее значение $-8,7 \%$. Для изготовления большинства предметов использованы приемы послелитейной обработки давлением, такие как ковка, штамповка, тиснение, чеканка, гравировка, чеканка. Два изделия - щиток перстня и чаша ложечки - изготовлены только с помощью литья; на ложечку также нанесен гравированный орнамент.
Оловянные латуни (сплав CuSnZn, в котором цинка больше чем олова) являются материалом для 8 изделий $(12,7$ \%), среди которых зеркало, пуговица, бляшка, ситечко, заклепка, перстень, сюльгама и браслет. Содержание меди колеблется от 74,7 до $95 \%$ (среднее значение $89 \%$ ), цинка от 2,4 до $17,7 \%$ (в среднем 6,3\%), олова от 1 до 7,3\% (среднее значение 2,5 \%). Три предмета были отлиты, еще пять были доработаны приемами ковки.

Из всей группы изделий, изготовленных из оловянных латуней, заметно отличается повышенными показателями содержания цинка и олова зеркало (табл. 1, 2). Для золотоордынских зеркал в целом нехарактерно изготовление из латуни, хотя встречаются экземпляры из многокомпонентных сплавов с небольшой примесью цинка [7, с. 127, 136].

К группе свинцовых латуней (CuPbZn, $\mathrm{Zn}>\mathrm{Pb}$ ) относятся 2 изделия: кованый браслет (Cu $81 \%, \mathrm{Zn} \mathrm{16,3 \% ,} \mathrm{Pb} \mathrm{1,5} \mathrm{\% )} \mathrm{и} \mathrm{массив-}$ ная литая тарелка (подставка) с высокими бортами (Cu 91,2 \%, Zn 5,4 \%, Pb 1,1 \%). Возможно, что содержащийся в такой невысокой концентрации $(1,1-1,3 \%)$ свинец является не искусственной лигатурой, а естественным компонентом плохо очищенной меди [7, с. 119].

Многокомпонентная латунь - сплав на основе меди, где в качестве лигатуры присутствуют олово, свинец и цинк, и цинка больше, чем олова. К этой группе относятся 7 изделий, среди которых пуговица, перстень, браслет, дужка, пластины и сюльгама. Содержание меди в сплаве колеблется в пределах $68,3-$ $91,8 \%$ (среднее значение 78,6\%), олова 1,3 $3,9 \%$ (среднее $2,2 \%$ ), свинца 1,3-12 \% (среднее 5,3 \%) и цинка 3,6-20,8 \% (среднее $12,4 \%$ ). 5 предметов изготовлены при помощи литья, 2 - доработаны приемами ковки.

Различные бронзы в изученной выборке составляют $42 \%$. К бронзам отнесены сплавы на основе меди, где в качестве лигатур использованы олово, свинец и цинк, а концентрация цинка не превышает процент содержания олова. Оловянные бронзы имеют хорошие механические свойства, применимы как для обработки давлением, так и для литья. Свойства сплава значительно меняются от концентрации олова - с увеличением его содержа- 
ния возрастает твердость сплава, но понижается пластичность [15, с. 155-156]. Из оловянной бронзы изготовлено 4 изделия, среди которых 2 зеркала, кольцо и матрица. Кольцо изготовлено приемами ковки литой заготовки, остальное - литьем. Кольцо и матрица содержат 6,1 и 9,4 \% олова соответственно. Зеркала отличаются повышенной концентрацией олова (23 и $24 \%)$, что делает их чрезвычайно хрупкими [14, с. 139]. По мнению Л.Ф. Недашковского, высокие концентрации олова в средневековых зеркалах характерны для местного производства, которое сложилось в золотоордынском Поволжье [13, с. 246].

Единичными экземплярами представлены изделия из свинцовой $(\mathrm{CuPb})$ и свинцовомышьяковистой (CuPbAs) бронзы. Известно, что свинец не входит в твердый раствор с медью, в сплаве располагается отдельными включениями [15, с. 161] и, таким образом, крайне плохо влияет на пластичность сплава. Кованая пластина (табл. 1, 58) покрыта трещинами (эффект красноломкости), появившимися именно из-за высокой концентрации свинца $(11,4 \%)$. Однако свинец в качестве лигатуры заметно повышает литейные свойства бронзы. Из свинцово-мышьяковистой бронзы $(\mathrm{Pb} \mathrm{2,4} \%$, As 3,2 \%) было изготовлено литое зеркало. Такой нехарактерный для золотоордынской металлообработки состав явился, вероятно, следствием переплавки других, более архаичных изделий. Мышьяковистые бронзы активно использовались задолго до рассматриваемого времени, в эпоху раннего железного века $[17$, с. $86 ; 1$, с. 65 и др.].

К оловянно-свинцовым бронзам относятся 5 изделий, все литые (зеркало, 2 колечка, 2 замочка в виде лошади). Один из предметов (кольцо, табл. 1,50 ) отличается наличием сурьмы (1,3\%), однако, скорее всего, это естественная примесь. Концентрация меди в этой группе изделий колеблется в пределах $71,2-90,9 \%$ (среднее значение $81,8 \%$ ); олово в пределах 4,8-18,1\% (среднее 12,4\%); свинец - 1,7-9,7 \% (среднее значение 4,1\%).

Как оловянно-цинковые бронзы определены сплавы меди с большей концентрацией олова, чем цинка. Примесь цинка значительно улучшает технологические свойства оловянных бронз [15, с. 161]. В изученной выборке к этой группе относятся 3 изделия: изго- товленный при помощи выколотки сосуд и литые наковаленка и пластина. Содержание меди варьируется в пределах 91,6-94,4 \% (среднее 92,7 \%), олова в пределах 2,4-6,1\% (среднее 3,9\%), цинка - 1,1-3,0 \%.

Многокомпонентные бронзы насчитывают 13 предметов, среди которых кольцо, замок, бляшки, слиток, зеркала, гирька, пластина, накладка, стержень, матрица и подвеска. Все вещи, кроме одного кованого кольца, изготовлены при помощи литья. Повышенной концентрацией свинца (18,2-41\%) отличается группа из 5 вещей (табл. 1, 28, 37, 46, 47, 49). Также для них отмечено повышенное содержание цинка $(7,8-15,8 \%)$. Для матрицы (табл. 1,37 ) такой состав стал причиной деформации, связанной с использованием в процессе тиснения [9, с. 98]. Однако, высокие доли свинца могут быть также связаны как с наличием коррозионного слоя, так и неравномерным распределением зерен свинца в сплаве, образовавшихся в процессе литья из-за низкой растворимости в меди (процесс ликвации).

Для остальных 8 изделий концентрация меди укладывается в пределах 56,9-89,8 \% (среднее значение 79,1\%), олова в пределах 4,4-32,6 \% (среднее 12,3\%), свинца в пределах 1,1-8,7 \% (среднее $3,3 \%$ ), а цинка - 1,6$6,1 \%$ (среднее $4,3 \%$ ).

Отдельную группу составляют все сплавы с драгоценными металлами - золотом и серебром. Три бляшки изготовлены из золото-серебряных сплавов с небольшим добавлением меди (сплав тройной системы). Из них две (табл. $1,14,15)$ образуют комплект, что подтверждается не только общей стилистикой, но и единой технологией изготовления (штамповка, чеканка), а также крайне близким элементным составом. Можно предположить, что два предмета были сделаны из одной порции металла (среднее значение концентраций: $\mathrm{Cu} 1,7$ \%, $\mathrm{Ag}$ 9,8, $\mathrm{Au} 86,7$ \%). Еще одна бляшка (табл. 1, 13), происходящая из некоего другого комплекта, изготовлена из сходного типа сплава с несколько иным содержанием основных компонентов (Cu 2,2 \%, Ag 30,9 \%, Au 62,3\%).

Три предмета изготовлены из многокомпонентного сплава на основе меди с повышенным содержанием серебра. По сути, это одно изделие - бляшка и два штифта, изготовлен- 


\section{СИМВОЛИЗМ И ТЕХНОЛОГИИ В МАТЕРИАЛЬНОЙ КУЛЬТУРЕ}

ные из одной порции металла (среднее значение: $\mathrm{Cu} 59,4$ \%, Sn 1,5 \%, Pb 1,6 \%, Zn 8, 4 , $\operatorname{Ag} 27,8 \%)$.

Присутствие серебра было зафиксировано на участке расположения припоя на двусоставной ложечке, которой была посвящена отдельная публикация [9, с. 98] (табл. 1, 61). Серебро, обладающее хорошей жидкотекучестью и высокой коррозионной стойкостью, относится к крепким припоям, использующимся для создания прочных соединений и пайки в том числе меди и бронзы [16, с. 429].

На трех бляшках (табл. 1, 11, 32, 33) зафиксированы остатки золочения по методу амальгирования, о чем свидетельствует наличие ртути. Метод заключается в нанесении на предварительно подогретую до определенной температуры поверхность сплава золота и ртути или золота, серебра и ртути - амальгамы. Две бляшки были покрыты золотом, еще одна - золото-серебряным сплавом. Расчет процентного содержания элементов в амальгаме дал следующие результаты: 1) $\mathrm{Au}$ $62 \%, \mathrm{Hg} 38 \%$; 2) Au $69 \%, \mathrm{Hg} 31 \%$; 3) Ag $55 \%$, Au 20\%, Hg $25 \%$. Полученные данные соотносятся с установленным наблюдением, что качественная амальгама должна содержать не менее $20 \%$ ртути [8, с. 60].

Результаты. Для сравнения результатов анализа коллекции с Селитренного городища привлечены опубликованные данные по Болгарскому Улусу Золотой Орды, Увекскому городищу и селищам его округи, а также Царевскому городищу и расположенному рядом с ним синхронному некрополю Бахтияровка $[7 ; 13 ; 10]$.

В материалах Селитренного городища отсутствуют изделия из «чистой» меди, в то время как в синхронной выборке Болгара процент таких изделий больше трети, а в выборке с Увека и его округи - почти пятая часть. Также полностью отсутствуют изделия из чистого свинца или свинцово-оловянного сплава, хотя в «увекской» коллекции такие вещи присутствуют. Оловянные бронзы в Болгаре представлены небольшим количеством проб, И.Е. Зайцева отметила отсутствие как таковой традиции использования оловянных бронз для изготовления украшений в золотоордынское время [7, с. 126]. В выборке из Увека и селищ его округи оловянные бронзы, наобо- рот, доминируют (40 \%), и связано это, по мнению Л.Ф. Недашковского, со значительным присутствием такой категории вещей как зеркала $[13$, с. 250$]$. В выборке с Селитренного городища оловянные бронзы присутствуют в незначительном количестве.

Изученный материал из раскопок Селитренного городища демонстрирует преобладание латуней и многокомпонентных сплавов. Доминирование латуней зафиксировано только на небольшой выборке из Царевского городища и курганных групп Бахтияровка. Для болгарских материалов отмечено снижение количества латуней, по сравнению с домонгольским периодом, и в целом они составляют небольшой процент выборок [7, с. 127]. Увекская выборка отличается крайне низким количеством латунных изделий - всего 2,7 \% $[13$, с. 250]. Невысокое содержание цинка в двойных и тройных латунях косвенно может свидетельствовать о вторичном использовании металла.

Существует устоявшийся тезис о том, что сложные рецептуры сплавов Средневековья редко были преднамеренными, они являлись результатом многочисленных переплавок металлов [4, с. 270]. Значительное число изделий из многокомпонентных бронз и латуней, в том числе и со значительной примесью серебра, позволяет говорить об устоявшейся на Селитренном городище практике использования металлического лома. Возможно, в переплавку попадали и достаточно архаичные вещи, благодаря которым в составе золотоордынских изделий фиксируется нехарактерный для этих сплавов мышьяк в относительно большом количестве.

Несмотря на то, что выделяются устойчивые группы (латуни, бронзы), концентрации в них элементов варьируются крайне широко, что говорит, скорее, об отсутствии четких рецептур. Внутри одной и той же категории вещей (например, зеркала) также слабо прослеживаются устойчивые рецептуры составления сплавов. Но прослеживается зависимость применяемой технологии от состава большинство латунных изделий обработаны приемами ковки, а для бронзовых вещей чаще использовалось литье.

Таким образом, исследованная выборка демонстрирует своеобразный и отличный от 
К. С. Ковалева. Материалы к изучению изделий из цветных и драгоценных металлов Селитренного городища

других крупных серий анализов золотоордынского времени характер.

\section{ПРИМЕЧАНИЯ}

1 Данные хранения: ГИМ 111012/оп. В 2694/ 2,3,5,6,7,12,13,16,20,29; ГИМ 109561/оп. В2739/2,1115; ГИМ 111016/оп. В 2680/13,14,28; ГИМ 111010/ оп. В 2692/19,33-35; ГИМ 111013/оп. В 2695/8,10,1317,19-21,32-36,38,39,41,43,46,47; ГИМ 111014/оп.
В 2696/25-29,32-36,41; ГИМ 111015/оп. В 2697/ 93,103,109,528.

2 Работа выполнена под руководством научного сотрудника Института археологии РАН, к.и.н. И.А. Сапрыкиной. Также выражаю благодарность руководству отдела археологических памятников Государственного исторического музея за предоставленную возможность работать с РФАспектрометром и микроскопом. Отдельно выражаю признательность за помощь в работе с коллекцией сотруднику отдела к.и.н. Е.М. Болдыревой. 


\section{СИМВОЛИЗМ И ТЕХНОЛОГИИ В МАТЕРИАЛЬНОЙ КУЛЬТУРЕ}

\section{ПРИЛОЖЕНИЕ}

Таблица 1. Результаты анализов предметов, происходящих с Селитренного городища Table 1. Results of analyses of items originating from Selitrennoe settlement

\begin{tabular}{|c|c|c|c|c|c|c|c|c|c|c|c|c|c|c|c|c|c|c|}
\hline $\begin{array}{c}\text { № } \\
\text { గா/ }\end{array}$ & 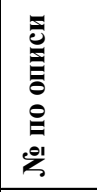 & 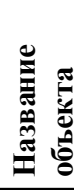 & 兰 & & & & ह & $\hat{2}$ & సี & $\frac{20}{4}$ & क & $\frac{2}{4}$ & I & $\overline{\mathbf{z}}$ & 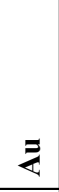 & $\stackrel{\infty 0}{ \pm}$ & 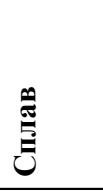 & 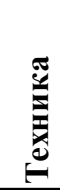 \\
\hline 1 & 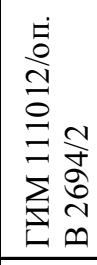 & $\begin{array}{l}\text { 氖 } \\
\text { 晋 }\end{array}$ & 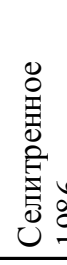 & 告 & & & $\overrightarrow{0}$ & $\overrightarrow{0}$ & $\stackrel{?}{=}$ & $\begin{array}{l}0 \\
0\end{array}$ & 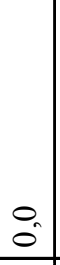 & : & $0_{0}$ & $\overrightarrow{0}$ & 8 & : & 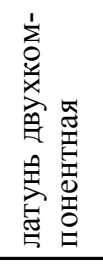 & 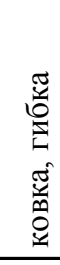 \\
\hline 2 & 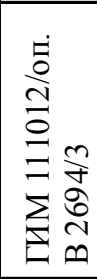 & 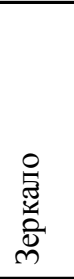 & 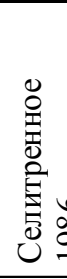 & 告 & & & $\stackrel{?}{2}$ & $\stackrel{0}{0}$ & $\underline{\Xi}$ & $\because$ & 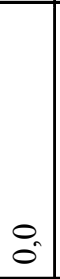 & : & $\hat{o}^{2}$ & $\stackrel{0}{0}$ & $\because$ & O & 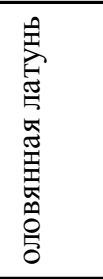 & 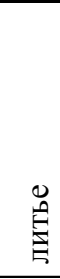 \\
\hline 3 & 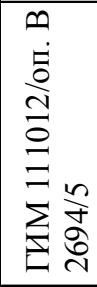 & 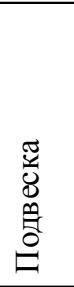 & 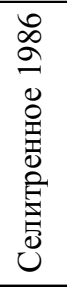 & 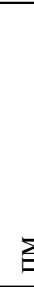 & & & $\overrightarrow{0}$ & $\tilde{o}^{n}$ & 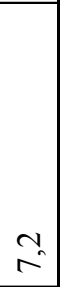 & 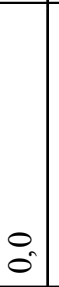 & $\ddot{0}_{0}$ & 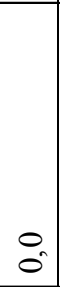 & $\overrightarrow{0}_{0}^{+}$ & $\overrightarrow{0}$ & $0_{0}^{\circ}$ & $\begin{array}{l}0 \\
0\end{array}$ & 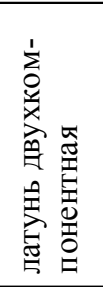 & 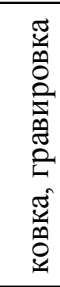 \\
\hline 4 & 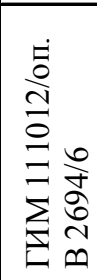 & 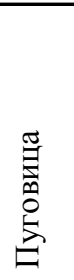 & 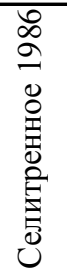 & $\frac{\approx}{\pi}$ & & & $\stackrel{i}{i}$ & $\overrightarrow{0}$ & $\begin{array}{l}\infty \\
+\end{array}$ & $\overrightarrow{0}$ & $\ddot{0}_{0}$ & 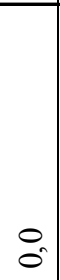 & $\tilde{o}$ & $\begin{array}{l}0 \\
0\end{array}$ & $0_{0}^{\circ}$ & $\begin{array}{l}0 \\
0\end{array}$ & 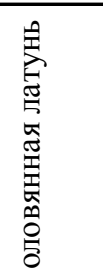 & 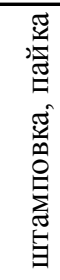 \\
\hline 5 & 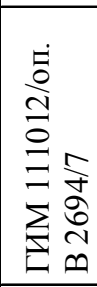 & 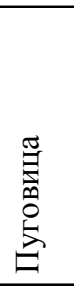 & 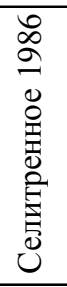 & in & & & $\because$ & $\stackrel{0}{i}$ & 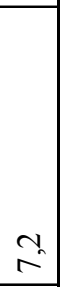 & 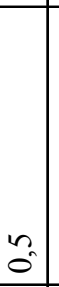 & $\therefore$ & ?a & $\tilde{3}$ & $\overrightarrow{0}$ & 8 & O. & 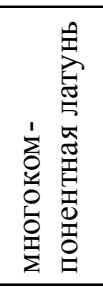 & 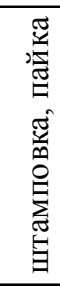 \\
\hline 6 & 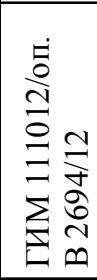 & 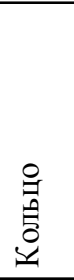 & 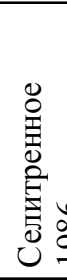 & 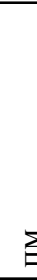 & & & $\stackrel{\circ}{\therefore}$ & $\stackrel{\infty}{\rightarrow}$ & $\stackrel{\infty}{m}$ & $\overrightarrow{0}$ & $\overrightarrow{0}$ & $\overrightarrow{0}$ & $n$ & $0_{0}^{\circ}$ & $\theta_{0}$ & $t_{0}^{t}$ & 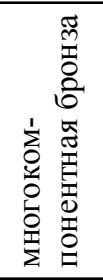 & 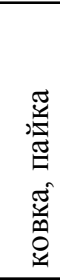 \\
\hline 7 & 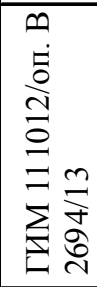 & 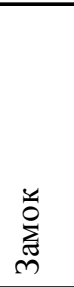 & 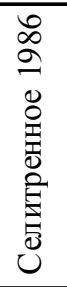 & & & 0 & $\begin{array}{l}0 \\
0^{0}\end{array}$ & $\begin{array}{c}0 \\
\tilde{n}^{n}\end{array}$ & $\stackrel{\sim}{\sim}$ & $\begin{array}{l}m \\
0\end{array}$ & $\overrightarrow{0}$ & 0 & $\overrightarrow{0}$ & 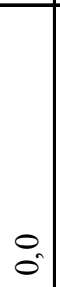 & $0_{0}^{0}$ & 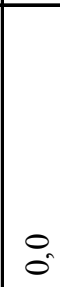 & 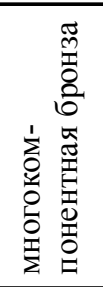 & 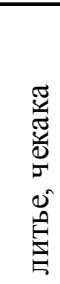 \\
\hline
\end{tabular}


Продолжение таблицы 1

Continuation of Table 1

\begin{tabular}{|c|c|c|c|c|c|c|c|c|c|c|c|c|c|c|c|c|c|}
\hline $\begin{array}{l}\text { № } \\
\text { గா/II }\end{array}$ & 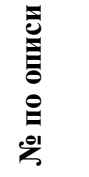 & 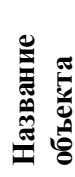 & 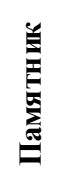 & $\frac{8}{2}$ & J & \#̈ & $\hat{2}$ & งี & $e_{4}^{\infty 0}$ & की & $\frac{2}{4}$ & I & $\bar{z}$ & 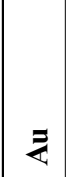 & $\stackrel{+00}{I}$ & 惢 & 莺 \\
\hline 8 & 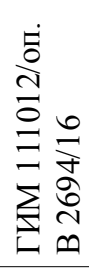 & 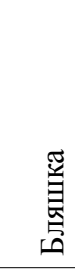 & 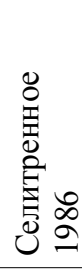 & 衣 & 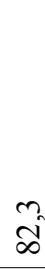 & $\begin{array}{c}3 \\
\infty\end{array}$ & $\stackrel{\vec{i}}{i}$ & $\overrightarrow{6}$ & r. & $\overrightarrow{0}$ & $\begin{array}{l}m \\
0\end{array}$ & $\overrightarrow{0}$ & $\ddot{0}_{0}$ & $0_{0}$ & $\overrightarrow{0}$ & 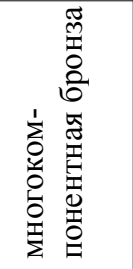 & 嵑 \\
\hline 9 & 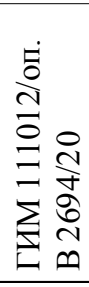 & $\begin{array}{r}5 \\
5 \\
\tilde{0} \\
\tilde{D} \\
\text { t. }\end{array}$ & 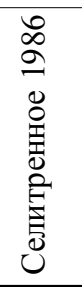 & 衣 & $\frac{0}{\infty}$ & हे & $\stackrel{n}{\simeq}$ & $\hat{\sigma}^{n}$ & $\overrightarrow{0}$ & 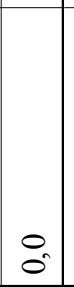 & $\because$ & $\tilde{\sigma}$ & $\because$ & $0_{0}$ & $\begin{array}{l}0 \\
0\end{array}$ & 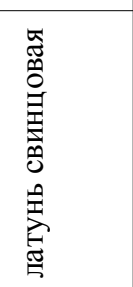 & 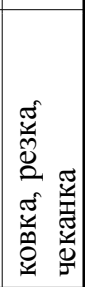 \\
\hline 10 & 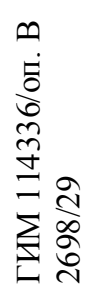 & 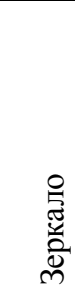 & $\begin{array}{l}8 \\
\vdots \\
0 \\
0 \\
\mathbb{E} \\
\mathbb{E} \\
\stackrel{0}{0} \\
0 \\
0 \\
0\end{array}$ & $\vec{x}$ & to & in & $\underset{f}{+}$ & $\ddot{0}_{0}$ & $\overrightarrow{0}$ & $\begin{array}{l}n \\
0\end{array}$ & $\begin{array}{l}0 \\
0\end{array}$ & $\begin{array}{l}n \\
i\end{array}$ & $0_{0}^{0}$ & $\begin{array}{l}0 \\
0^{\circ}\end{array}$ & $\overrightarrow{0}$ & 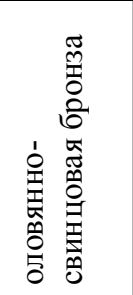 & $\begin{array}{l}0 \\
\stackrel{0}{:} \\
\text { 至 }\end{array}$ \\
\hline 11 & 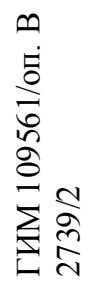 & 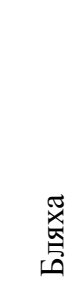 & 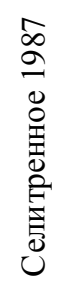 & 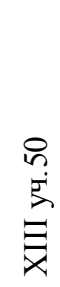 & ֶె & $\overrightarrow{0}$ & $n$ & $\exists$ & $\overrightarrow{0}$ & $\begin{array}{l}0 \\
0\end{array}$ & $\begin{array}{l}0 \\
0\end{array}$ & $\overrightarrow{0}$ & $0_{0}^{0}$ & $\underset{\sim}{\stackrel{\Delta}{r}}$ & $\begin{array}{l}n \\
\dot{\gamma}\end{array}$ & $\begin{array}{l}\mathscr{0} \\
\stackrel{1}{0} \\
0 \\
0 \\
0 \\
0 \\
0\end{array}$ & 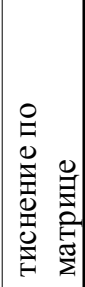 \\
\hline & & 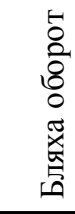 & 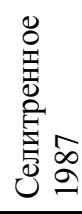 & 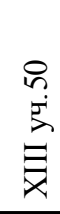 & $\begin{array}{l}\vec{\infty} \\
\ddot{\infty}\end{array}$ & $\overline{0}$ & $\hat{0}$ & $\tilde{n}$ & $\overrightarrow{0}$ & O. & $\begin{array}{l}0 \\
0\end{array}$ & $\overrightarrow{0}$ & 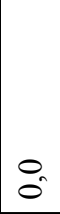 & $0_{0}^{\circ}$ & $\overrightarrow{0}$ & 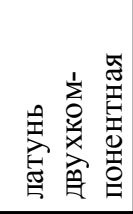 & \\
\hline 12 & 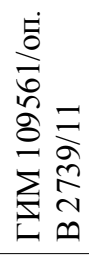 & 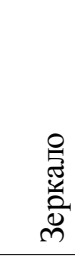 & 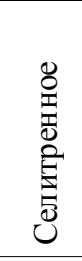 & え & $\vec{\sigma}$ & $\stackrel{\infty}{0}$ & $\stackrel{t}{i}$ & $\because$ & ro & $\overrightarrow{0}$ & $\tilde{n}^{1}$ & శn & $\overrightarrow{0}$ & $0_{0}$ & $0_{0}^{0}$ & 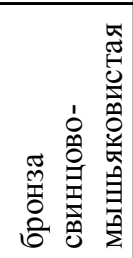 & $\begin{array}{l}0 \\
\stackrel{0}{E} \\
\end{array}$ \\
\hline 13 & 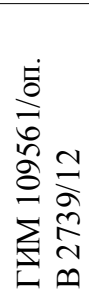 & 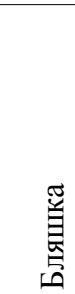 & 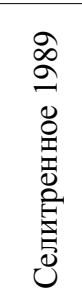 & 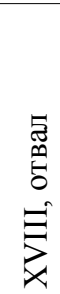 & $\tilde{N}$ & $\tilde{0}^{2}$ & $\overrightarrow{0}$ & $0_{0}^{0}$ & $\hat{\text { हे }}$ & $\begin{array}{l}0 \\
0\end{array}$ & O. & $\stackrel{m}{m}$ & 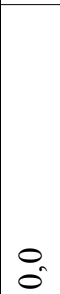 & $\hat{\tilde{b}}$ & ${ }_{0}^{\infty}$ & 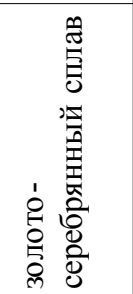 & 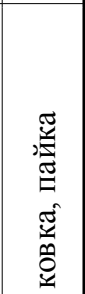 \\
\hline
\end{tabular}




\section{СИМВОЛИЗМ И ТЕХНОЛОГИИ В МАТЕРИАЛЬНОЙ КУЛЬТУРЕ}

Продолжение таблицы 1

Continuation of Table 1

\begin{tabular}{|c|c|c|c|c|c|c|c|c|c|c|c|c|c|c|c|c|c|}
\hline $\begin{array}{l}\text { № } \\
\Pi \mathbf{\Pi} / \mathbf{n}\end{array}$ & 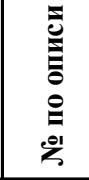 & 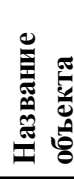 & 岂 & $\begin{array}{l}\stackrel{8}{E} \\
\sum\end{array}$ & $\Xi$ & क & $\hat{2}$ & งี & 200 & क & q & 品 & $\overline{\mathbf{z}}$ & $z$ & $\stackrel{+\infty}{ \pm}$ & 慈 & 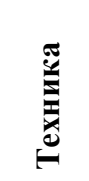 \\
\hline 14 & 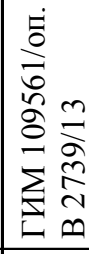 & 算 & 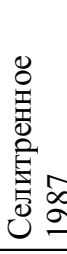 & $\sum$ & $\approx$ & $\overrightarrow{0}$ & $\tilde{s}$ & $\overrightarrow{0}$ & $\vec{\infty}$ & $\begin{array}{l}0 \\
0\end{array}$ & $\ddot{0}$ & $\tilde{o}^{n}$ & $\begin{array}{l}0 \\
0\end{array}$ & $\begin{array}{l}0 \\
\infty \\
\infty\end{array}$ & $\hat{0}$ & 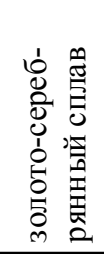 & 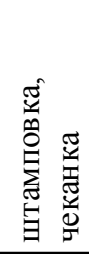 \\
\hline 15 & 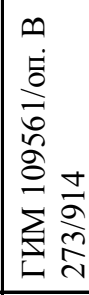 & 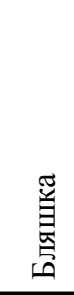 & 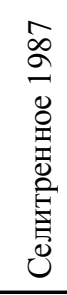 & 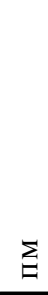 & $\approx$ & 3 & $\begin{array}{l}0 \\
0\end{array}$ & $\overrightarrow{0}$ & $\begin{array}{l}0 \\
=\end{array}$ & $\theta_{0}$ & $\ddot{0}_{0}$ & $\ddot{0}_{0}^{0}$ & $\begin{array}{l}0 \\
0\end{array}$ & $\begin{array}{l}\text { के } \\
\dot{\infty}\end{array}$ & $\hat{0}$ & 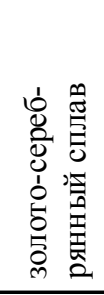 & 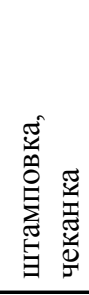 \\
\hline 16 & 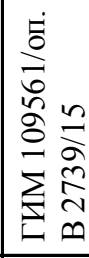 & 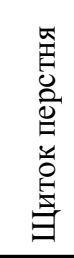 & 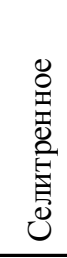 & 衣 & $\begin{array}{l}0 \\
\infty\end{array}$ & $\overrightarrow{0}$ & $3_{0}^{m}$ & $\hat{\vartheta}^{2}$ & $\overrightarrow{0}$ & $\theta_{0}$ & $0_{0}$ & 3. & 0 & 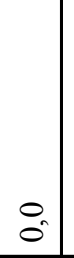 & 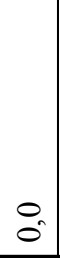 & 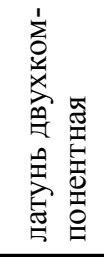 & 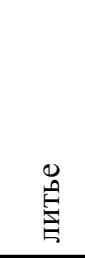 \\
\hline 17 & 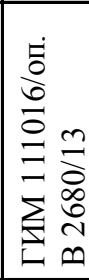 & 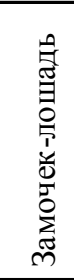 & 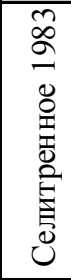 & 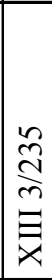 & $\hat{\infty}$ & $\stackrel{0}{\cong}$ & $\approx$ & $\ddot{0}$ & $3^{2}$ & $\theta_{0}^{0}$ & $0_{0}^{\circ}$ & $\overrightarrow{0}$ & O. & $\begin{array}{l}0 \\
0\end{array}$ & : & 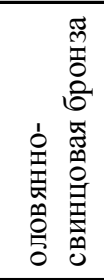 & 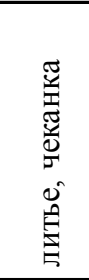 \\
\hline 18 & 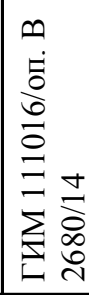 & 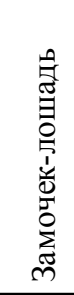 & 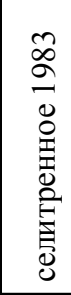 & 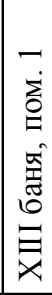 & $\stackrel{ }{\pi}$ & $\vec{\infty}$ & $\hat{a}$ & $\overrightarrow{0}$ & on & $0_{0}^{\circ}$ & $\tilde{0}$ & $\tilde{o}^{n}$ & : & 0 & $\because$ & 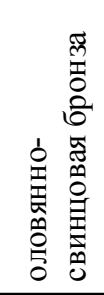 & 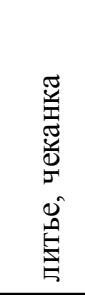 \\
\hline 19 & 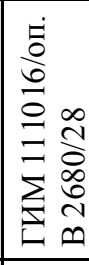 & \begin{tabular}{l} 
呇 \\
\hdashline
\end{tabular} & 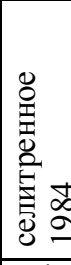 & 衣 & $\frac{0}{a}$ & $\overrightarrow{6}$ & ? & $=$ & $\overrightarrow{0}$ & $\overrightarrow{0}$ & $\stackrel{+}{0}$ & $\overrightarrow{0}$ & $\overrightarrow{0}$ & $0_{0}^{\circ}$ & $\because$ & 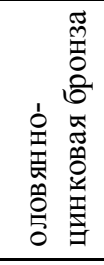 & 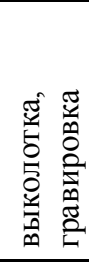 \\
\hline 20 & 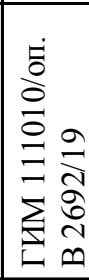 & 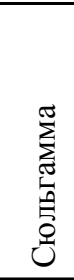 & 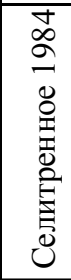 & $\sum$ & $\frac{a}{a}$ & $\stackrel{\infty}{\rightarrow}$ & $\overrightarrow{0}_{0}^{+}$ & $\vec{n}$ & $\hat{0}_{0}^{m}$ & $\overrightarrow{0}$ & $=$ & $\hat{0}_{0}^{n}$ & $\overrightarrow{0}$ & $\begin{array}{l}0 \\
0\end{array}$ & $\tilde{o}$ & 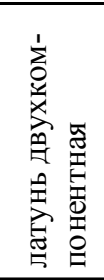 & 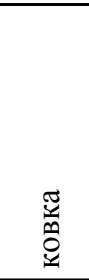 \\
\hline
\end{tabular}


Продолжение таблицы 1

Continuation of Table 1

\begin{tabular}{|c|c|c|c|c|c|c|c|c|c|c|c|c|c|c|c|c|c|c|}
\hline $\begin{array}{c}\text { № } \\
\text { ா/III }\end{array}$ & 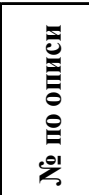 & 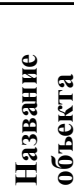 & 岂 & $\frac{8}{8}$ & $\Xi$ & के & $\hat{2}$ & 5 & 8 & 20 & की & द & I & $\overline{\mathbf{z}}$ & $\Xi$ & $\stackrel{000}{ \pm}$ & 总 & 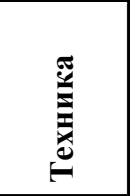 \\
\hline 21 & 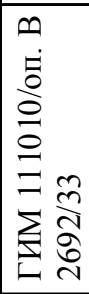 & 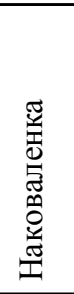 & 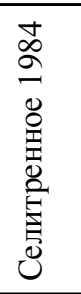 & 衣 & $\begin{array}{l}+ \\
\dot{a}\end{array}$ & $\stackrel{ \pm}{i}$ & $\hat{o}$ & ? & & 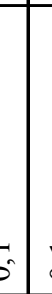 & $\overrightarrow{0}$ & $\tilde{0}^{n}$ & $\overrightarrow{0}$ & $\overrightarrow{0}$ & $\ddot{0}^{n}$ & $\begin{array}{l}0 \\
0\end{array}$ & 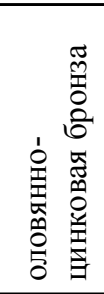 & $\stackrel{0}{\stackrel{0}{E}}$ \\
\hline 22 & 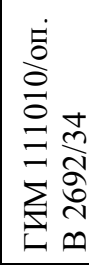 & 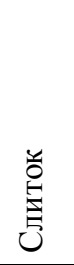 & 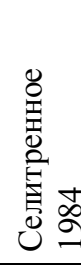 & $\bar{\xi}$ & $\begin{array}{l}\infty \\
\infty\end{array}$ & $\vec{g}$ & $=$ & o & & $\begin{array}{l}3 \\
-1\end{array}$ & $\overrightarrow{0}$ & $\tilde{o}$ & $\tilde{o}_{0}^{1}$ & శ̊. & $\because$ & $\overrightarrow{0}$ & 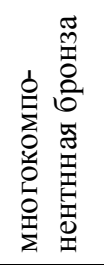 & $\begin{array}{l}0 \\
\stackrel{\Theta}{E}\end{array}$ \\
\hline 23 & 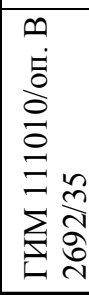 & 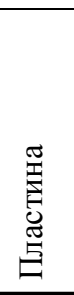 & 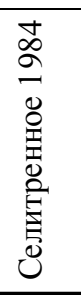 & $\begin{array}{l}n \\
\stackrel{n}{7} \\
\Xi \\
\exists\end{array}$ & ลี & $\stackrel{\nabla}{\vec{r}}$ & 3 & s & & 8 & $\overrightarrow{0}$ & $\tilde{0}$ & $\tilde{o}^{1}$ & ô. & $0^{0}$ & $\because$ & 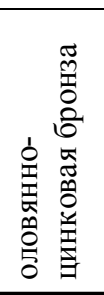 & 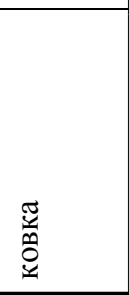 \\
\hline 24 & 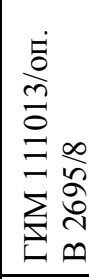 & $\begin{array}{l}\hat{A} \\
\stackrel{\Xi}{0} \\
\stackrel{0}{0} \\
\stackrel{0}{\theta}\end{array}$ & 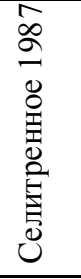 & $\bar{\xi}$ & $\stackrel{m}{0}$ & ते & co & & & 8 & $\overrightarrow{0}$ & $\begin{array}{l}0 \\
0\end{array}$ & $\hat{0}$ & $\begin{array}{l}0 \\
0\end{array}$ & $\stackrel{0}{0}^{\circ}$ & $\because$ & 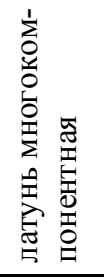 & 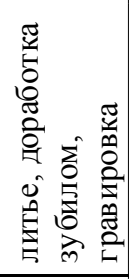 \\
\hline 25 & 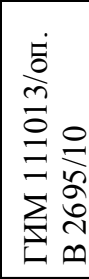 & 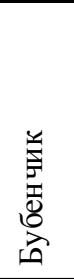 & 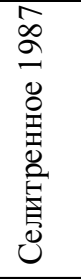 & 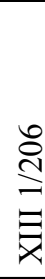 & $\begin{array}{l}t \\
\circ\end{array}$ & $\bar{c}$ & c & $\delta$ & & $\overrightarrow{0}$ & $\begin{array}{l}0 \\
0\end{array}$ & $O_{0}$ & $\hat{o}_{0}^{2}$ & 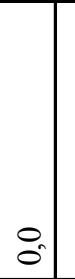 & $\ddot{0}_{0}$ & $\ddot{0}$ & 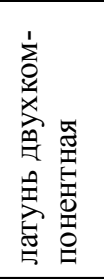 & 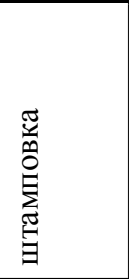 \\
\hline 26 & 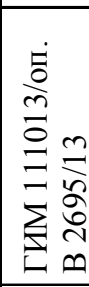 & $\begin{array}{l}5 \\
5 \\
5 \\
\tilde{0} \\
\tilde{n}\end{array}$ & 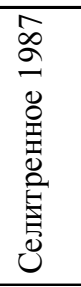 & $\underline{\Xi}$ & 3 & 9 & $\vec{v}$ & $\delta$ & & $\Rightarrow$ & $\overrightarrow{0}$ & $\ddot{0}_{0}$ & $\tilde{o}^{n}$ & $\begin{array}{l}0 \\
0\end{array}$ & $\begin{array}{l}0 \\
0\end{array}$ & $\overrightarrow{0}$ & 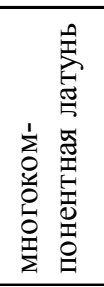 & 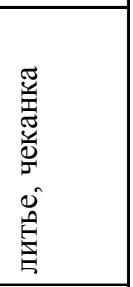 \\
\hline 27 & 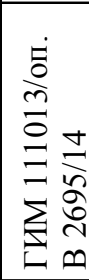 & 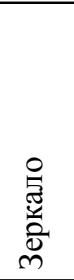 & 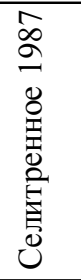 & 囟 & రे & $\approx$ & $\stackrel{9}{7}$ & 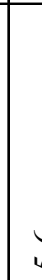 & & $\overrightarrow{0}$ & $\overrightarrow{0}$ & $\overrightarrow{0}$ & $\overrightarrow{0}$ & 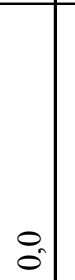 & $\begin{array}{l}0 \\
0\end{array}$ & $\overrightarrow{0}$ & 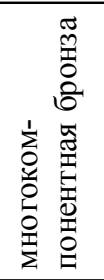 & $\begin{array}{l}0 \\
\stackrel{E}{E}\end{array}$ \\
\hline
\end{tabular}


Продолжение таблицы 1

Continuation of Table 1

\begin{tabular}{|c|c|c|c|c|c|c|c|c|c|c|c|c|c|c|c|c|c|}
\hline $\begin{array}{c}\text { № } \\
\mathbf{n} / \mathbf{I}\end{array}$ & 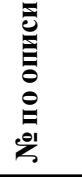 & 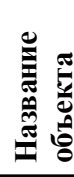 & 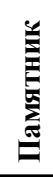 & 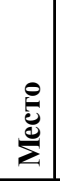 & $\tilde{J}$ & है & $\overrightarrow{\mathrm{a}}$ & ธี & 紫 & $\vec{n}$ & $\frac{2}{4}$ & 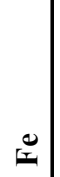 & $\overline{\mathbf{z}}$ & $\exists$ & $\stackrel{000}{ \pm}$ & 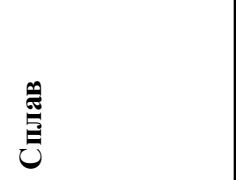 & 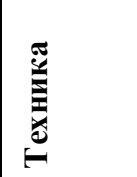 \\
\hline 28 & 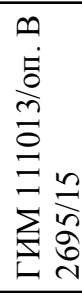 & 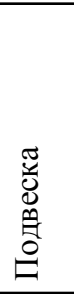 & $\begin{array}{l}1 \\
0 \\
2 \\
8 \\
0 \\
0 \\
0 \\
0 \\
0 \\
0 \\
0\end{array}$ & $\bar{\Xi}$ & 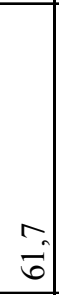 & $\stackrel{0}{=}=$ & $\begin{array}{c}1 \\
\infty \\
-1\end{array}$ & $\stackrel{\infty}{\sim}$ & $\begin{array}{l}+ \\
0 \\
0\end{array}$ & $\overrightarrow{0}$ & $\overrightarrow{0}$ & $\begin{array}{l}n \\
0\end{array}$ & $\overrightarrow{0}$ & 8 & $\overrightarrow{0}$ & 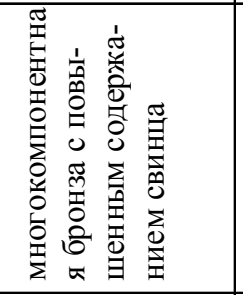 & $\begin{array}{l}0 \\
\stackrel{E}{E}\end{array}$ \\
\hline 29 & 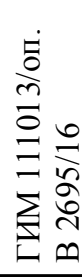 & 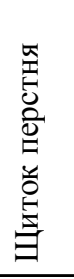 & 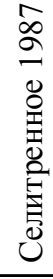 & 引 & $\begin{array}{l}0 \\
\infty \\
\infty\end{array}$ & 8 & $\stackrel{0}{-}$ & $\begin{array}{l}0 \\
2 \\
-\end{array}$ & : & $\begin{array}{l}0 \\
0\end{array}$ & $\begin{array}{l}0 \\
0 \\
\end{array}$ & $\overrightarrow{0}$ & $\begin{array}{l}0 \\
0 \\
0\end{array}$ & $\begin{array}{l}0 \\
0\end{array}$ & $\overrightarrow{0}$ & 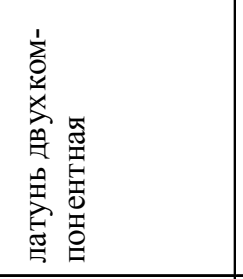 & 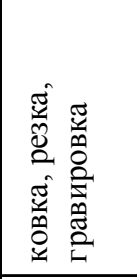 \\
\hline 30 & 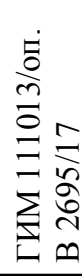 & 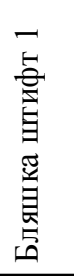 & 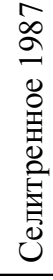 & $\bar{\Xi}$ & $\begin{array}{l}n \\
n \\
n \\
n\end{array}$ & $\because$ & $\because$ & $\begin{array}{l}0 \\
= \\
=\end{array}$ & $\begin{array}{l}n \\
\hat{\imath} \\
\end{array}$ & $\begin{array}{l}0 \\
0\end{array}$ & 8 & $\begin{array}{l}\infty \\
0 \\
0\end{array}$ & $\begin{array}{l}0 \\
0\end{array}$ & $\begin{array}{c}1 \\
0\end{array}$ & $=$ & 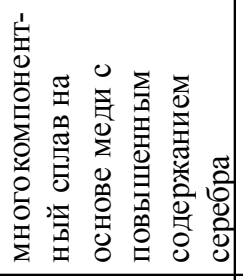 & 丞 \\
\hline 31 & 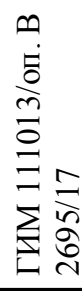 & 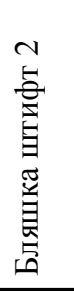 & 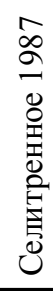 & ఏ & $\begin{array}{c}\text { के } \\
\infty \\
n\end{array}$ & $\approx$ & 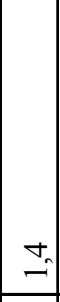 & $\stackrel{2}{\sim}$ & $\begin{array}{l}n \\
2 \\
2\end{array}$ & $\overrightarrow{0}$ & $\overrightarrow{0}$ & $\begin{array}{l}n \\
0\end{array}$ & $\begin{array}{l}0 \\
0 \\
0\end{array}$ & $\begin{array}{c}n \\
0\end{array}$ & $=$ & 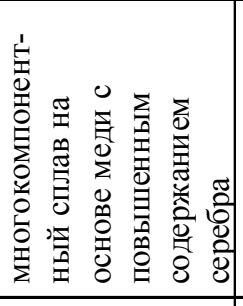 & ঙ্: \\
\hline 32 & 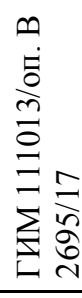 & 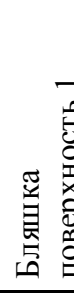 & $\begin{array}{l}\hat{\infty} \\
2 \\
0 \\
0 \\
0 \\
0 \\
0 \\
0 \\
0 \\
0 \\
0\end{array}$ & 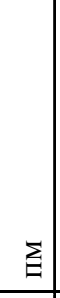 & ते & $\because$ & $=$ & $\sigma_{0}$ & $\begin{array}{l}0 \\
\hat{\imath} \\
\end{array}$ & 0 & 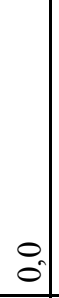 & $\begin{array}{l}0 \\
0 \\
0\end{array}$ & $\overrightarrow{0}$ & ก) & ?. & 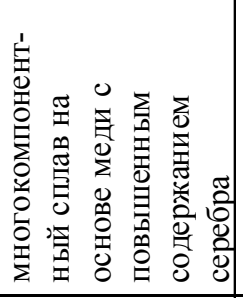 & 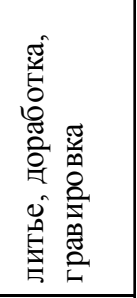 \\
\hline & & 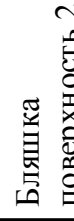 & & & $\begin{array}{l}+ \\
\vec{\lambda}\end{array}$ & $\stackrel{3}{-1}$ & $\begin{array}{l}m \\
0\end{array}$ & $\tilde{r}$ & $\begin{array}{l}\hat{\imath} \\
\hat{\imath}\end{array}$ & $\ddot{0}$ & $\overrightarrow{0}$ & 今̂ & 0 & $\frac{m}{m}$ & $\begin{array}{l}m \\
\stackrel{ \pm}{-}\end{array}$ & 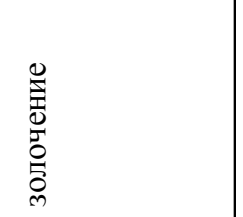 & 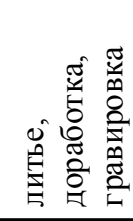 \\
\hline
\end{tabular}


Продолжение таблицы 1

Continuation of Table 1

\begin{tabular}{|c|c|c|c|c|c|c|c|c|c|c|c|c|c|c|c|c|c|c|}
\hline $\begin{array}{c}\text { № } \\
\text { חI/ா }\end{array}$ & 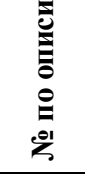 & 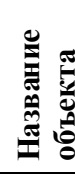 & 宸 & $\begin{array}{l}\frac{8}{0} \\
\sum^{e}\end{array}$ & $\Xi$ & $\bar{n}$ & 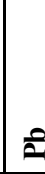 & งี & 年 & $\delta$ & $\hat{n}$ & ₹ & $\Phi$ & $\overline{\mathbf{z}}$ & $\bar{z}$ & $\stackrel{000}{ \pm}$ & 总 & 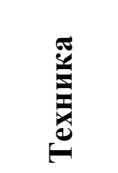 \\
\hline 33 & 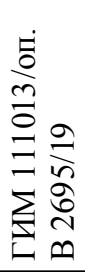 & 焉 & 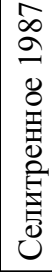 & 衣 & in & $=$ & $\stackrel{0}{0}$ & r & $\begin{array}{l}0 \\
\stackrel{0}{2}\end{array}$ & 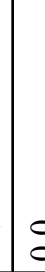 & 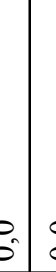 & $\theta_{0}^{0}$ & $\begin{array}{l}\infty \\
0 \\
0\end{array}$ & 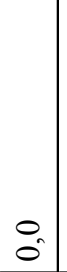 & $\vec{\sigma}$ & $\tilde{a}^{n}$ & 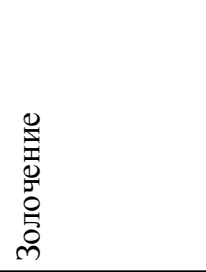 & 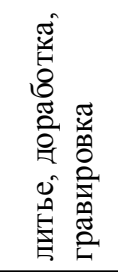 \\
\hline & & 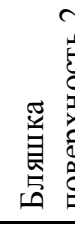 & & & $\begin{array}{l}\infty \\
a \\
a\end{array}$ & $\overrightarrow{0}$ & $\stackrel{t}{0}$ & nz & ? & $\varepsilon$ & 8 & $\theta_{0}$ & $\tilde{o}$ & $\overrightarrow{0}$ & $\stackrel{0}{0}$ & $\theta_{0}$ & 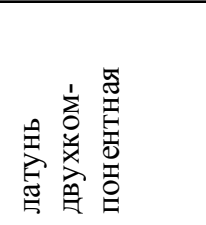 & 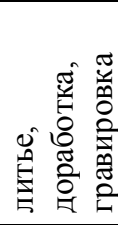 \\
\hline 34 & 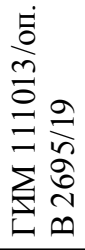 & 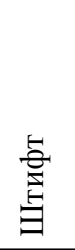 & & & ठे & $\begin{array}{l}\infty \\
0\end{array}$ & $\stackrel{0}{0}$ & in & $\stackrel{m}{n}$ & 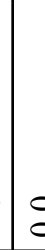 & 8 & O. & $\stackrel{t}{0}$ & $\overrightarrow{0}$ & $\overrightarrow{0}$ & $\overrightarrow{0}$ & 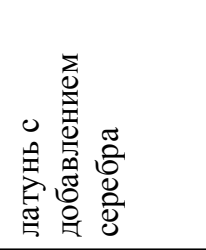 & 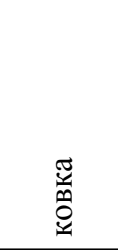 \\
\hline 35 & 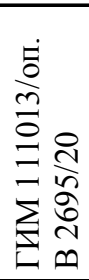 & 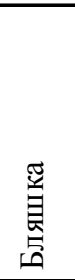 & 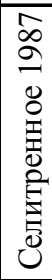 & 衣 & $\vec{d}$ & $\overrightarrow{0}$ & ? & $\underset{t}{t}$ & $\overline{0}$ & 8 & 8 & $\begin{array}{l}0 . \\
0 \\
0\end{array}$ & ?. & $\because$ & $\because$ & $\begin{array}{l}0 \\
0\end{array}$ & 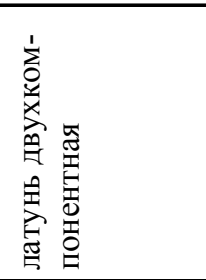 & 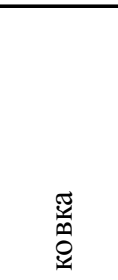 \\
\hline 36 & 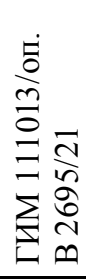 & $\begin{array}{l}\text { 舀 } \\
\text { 空 }\end{array}$ & 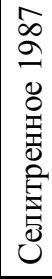 & 囟 & $\bar{a}$ & 二 & $\stackrel{0}{\circ}$ & $\stackrel{7}{n}$ & $\overline{0}$ & c & $\dot{0}$ & $\overrightarrow{0}$ & m. & $\because$ & $\because$ & $\because$ & 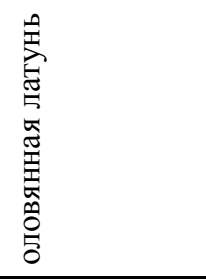 & 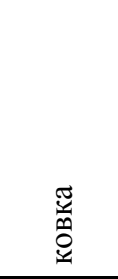 \\
\hline 37 & 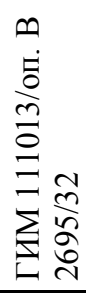 & 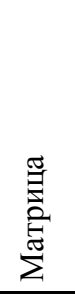 & 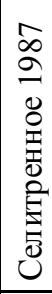 & 气 & 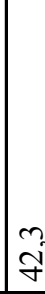 & $\bar{\infty}$ & $\overline{7}$ & $0_{\infty}^{0}$ & $\overline{0}$ & $\bar{c}$ & $\overrightarrow{0}$ & $\overrightarrow{0}$ & $\overrightarrow{0}$ & $\theta_{0}^{\circ}$ & $\because$ & $0_{0}^{\circ}$ & 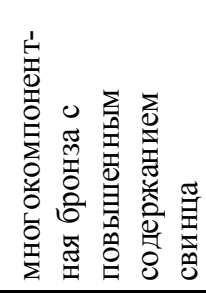 & 息 \\
\hline 38 & 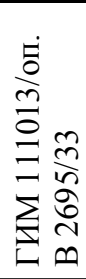 & 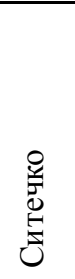 & 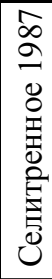 & 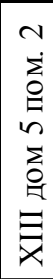 & ga & ב & : & $\stackrel{c}{m}$ & $\tilde{c}$ & $\varepsilon$ & 8 & $\begin{array}{l}0 . \\
0\end{array}$ & $\overrightarrow{0}$ & $\overrightarrow{0}$ & $\ddot{O}_{0}$ & $\theta_{0}^{0}$ & 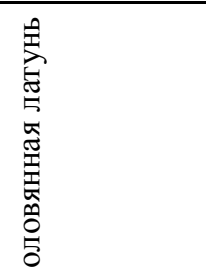 & 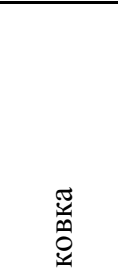 \\
\hline
\end{tabular}




\section{СИМВОЛИЗМ И ТЕХНОЛОГИИ В МАТЕРИАЛЬНОЙ КУЛЬТУРЕ}

Продолжение таблицы 1

Continuation of Table 1

\begin{tabular}{|c|c|c|c|c|c|c|c|c|c|c|c|c|c|c|c|c|c|}
\hline $\begin{array}{c}\text { № } \\
\text { חI/II }\end{array}$ & 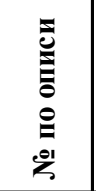 & 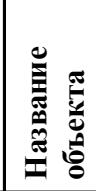 & 曾 & $\frac{\overbrace{}^{\circ}}{\sum^{\circ}}$ & $\bar{J}$ & है & $\hat{A}$ & $\tilde{\mathbf{N}}$ & 200 & $\vec{n}$ & $\frac{2}{4}$ & $\underset{I}{0}$ & $\bar{z}$ & 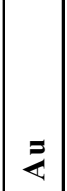 & \pm & 善 & 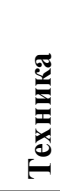 \\
\hline 39 & 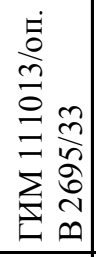 & 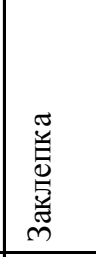 & & & $\begin{array}{l}: \\
a\end{array}$ & $\because$ & $\begin{array}{l}0 \\
0\end{array}$ & $\stackrel{+}{\mathrm{s}}$ & 0 & $\because$ & $\overline{0}$ & $\stackrel{1}{0}$ & 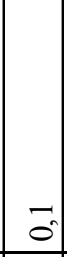 & 8 & 8 & 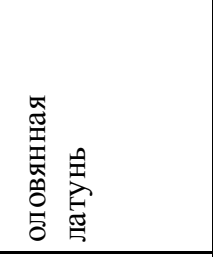 & 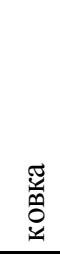 \\
\hline 40 & 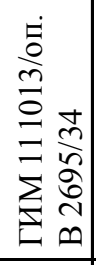 & 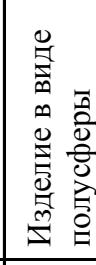 & 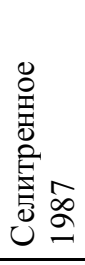 & 吉 & $\stackrel{2}{a}$ & $\bar{c}$ & ?. & i & $\overrightarrow{0}$ & $\overrightarrow{0}$ & $\overrightarrow{0}$ & $\overrightarrow{0}$ & 8 & 8 & 8 & 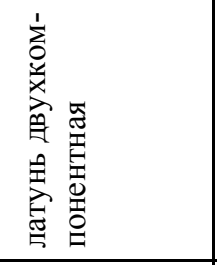 & 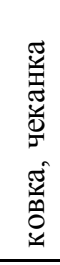 \\
\hline 41 & 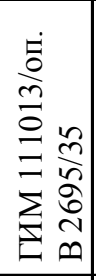 & 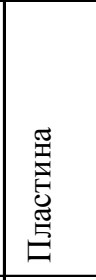 & 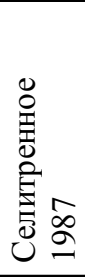 & 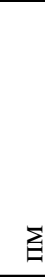 & $\begin{array}{l}0 \\
\stackrel{n}{n}\end{array}$ & $\stackrel{\infty}{m}$ & ते & $\begin{array}{l}\infty \\
n \\
n\end{array}$ & $\overrightarrow{0}$ & $\overrightarrow{0}$ & 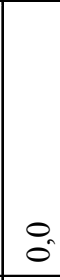 & $\hat{0}_{0}$ & 0 & $\begin{array}{l}0 \\
0\end{array}$ & ?3. & 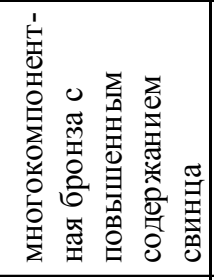 & $\begin{array}{l}\text { 足 } \\
\stackrel{\Delta}{E}\end{array}$ \\
\hline 42 & 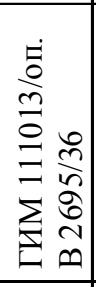 & 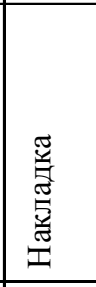 & 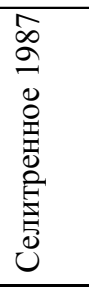 & 囟 & $\stackrel{\sigma}{\tilde{f}}$ & $\stackrel{m}{+}$ & $\frac{\pi}{m}$ & 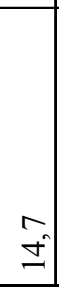 & 0 & of & $\because$ & $\because$ & 8 & $\begin{array}{l}0 \\
0\end{array}$ & 0 & 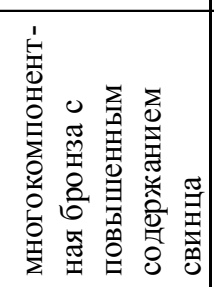 & 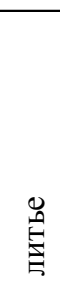 \\
\hline 43 & 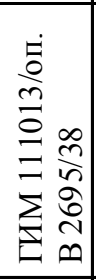 & 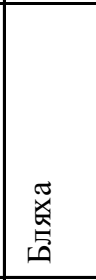 & 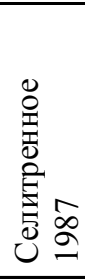 & 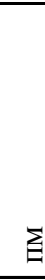 & $\hat{i}$ & $\stackrel{+}{2}$ & $\begin{array}{c}0 \\
m\end{array}$ & हो & ? & 0 & : & $3^{2}$ & $\overrightarrow{0}$ & 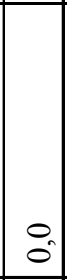 & $\begin{array}{l}0 \\
0\end{array}$ & 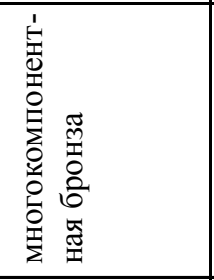 & 惫 \\
\hline 44 & 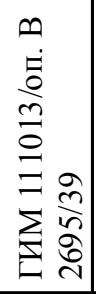 & 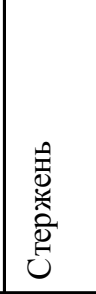 & 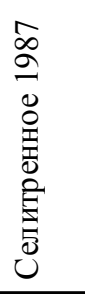 & 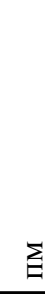 & $\vec{\infty}$ & 广 & \begin{tabular}{l}
$\sim$ \\
\multirow{2}{*}{}
\end{tabular} & $\begin{array}{l}0 \\
= \\
=\end{array}$ & 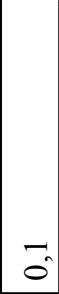 & $=$ & $\because$ & $\stackrel{\infty}{\circ}$ & $\overrightarrow{0}$ & O & $\overrightarrow{0}$ & 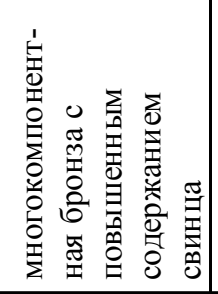 & $\begin{array}{l}\text { 足 } \\
\text { 思 }\end{array}$ \\
\hline 45 & 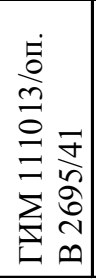 & 离 & 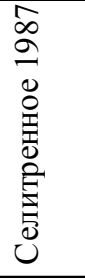 & 亩 & $\stackrel{n}{\stackrel{n}{r}}$ & $\hat{n}$ & $\begin{array}{l}n \\
\sigma\end{array}$ & $\begin{array}{l}n \\
0 \\
0\end{array}$ & $\because$ & $\overrightarrow{0}$ & $\overrightarrow{0}$ & $\stackrel{n}{\Rightarrow}$ & $\begin{array}{l}0 \\
0\end{array}$ & $\begin{array}{l}0 \\
0\end{array}$ & $\overrightarrow{0}$ & 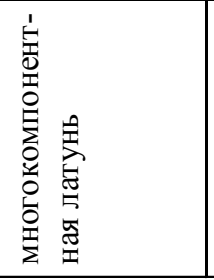 & $\begin{array}{l}\text { 思 } \\
\end{array}$ \\
\hline
\end{tabular}


Продолжение таблицы 1

Continuation of Table 1

\begin{tabular}{|c|c|c|c|c|c|c|c|c|c|c|c|c|c|c|c|c|c|}
\hline 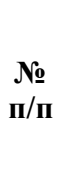 & 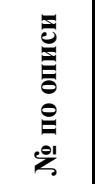 & 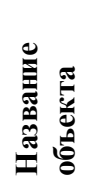 & & $\begin{array}{l}\overbrace{0}^{\circ} \\
\sum\end{array}$ & E & क & $\hat{2}$ & 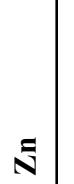 & 20 & क & 2 & $\nsubseteq$ & $\mathbf{z}$ & $\exists$ & $\stackrel{000}{ \pm}$ & 憑 & 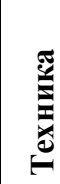 \\
\hline 46 & 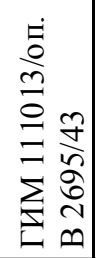 & 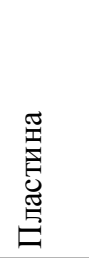 & 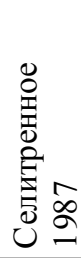 & $\begin{array}{l}\underset{O}{N} \\
\frac{1}{m} \\
\vec{x} \\
x\end{array}$ & $\begin{array}{l}t_{0} \\
\dot{0}\end{array}$ & $\stackrel{\sigma_{n}}{-}$ & $\stackrel{m}{\rightarrow}$ & $\stackrel{+}{\circ}$ & $\overrightarrow{0}$ & $\because$ & $\because$ & $\begin{array}{l}n \\
0\end{array}$ & $\begin{array}{l}0 \\
0\end{array}$ & $\begin{array}{l}0 \\
0\end{array}$ & $=$ & 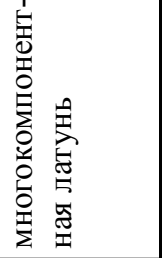 & 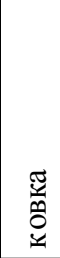 \\
\hline 47 & 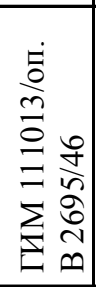 & 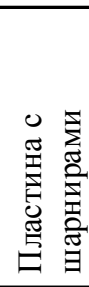 & 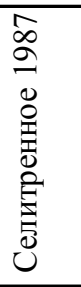 & $\begin{array}{l}\text { N } \\
\dot{\bar{\Sigma}} \\
\stackrel{1}{日} \\
\dot{x}\end{array}$ & $\frac{\infty}{i}$ & $\stackrel{+}{-}$ & $\begin{array}{l}\hat{i} \\
\mathrm{i}\end{array}$ & $\begin{array}{l}\infty \\
\stackrel{-}{2}\end{array}$ & $\begin{array}{l}0 \\
0\end{array}$ & $\because$ & : & $\begin{array}{l}0 \\
0 \\
0\end{array}$ & $\overrightarrow{0}$ & $\begin{array}{l}0 \\
0\end{array}$ & 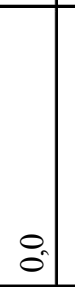 & 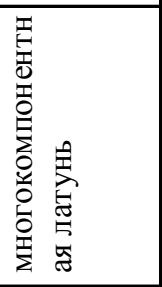 & 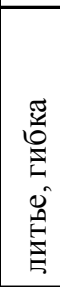 \\
\hline 48 & 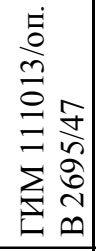 & 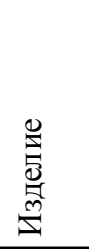 & 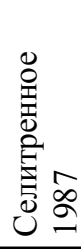 & $\begin{array}{l}N \\
\dot{\vdots} \\
0 \\
\dot{G} \\
\dot{x}\end{array}$ & $\frac{\sigma}{\sigma}$ & $\overrightarrow{0}$ & $\tilde{0}$ & $\begin{array}{l}0 \\
\therefore\end{array}$ & $\theta_{0}$ & 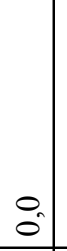 & ת) & 今. & $\overrightarrow{0}$ & $\begin{array}{l}0 \\
0\end{array}$ & ڤै- & 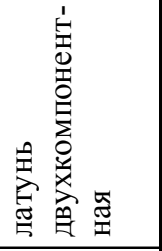 & 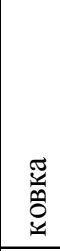 \\
\hline 49 & 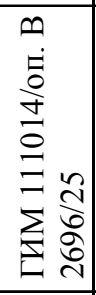 & 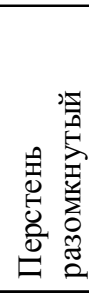 & 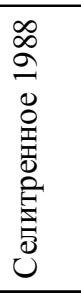 & $\underline{\Xi}$ & $\stackrel{+}{8}$ & $\stackrel{0}{=}$ & $3_{0}^{2}$ & $\hat{\sim}$ & ช̂ & $\overrightarrow{0}$ & 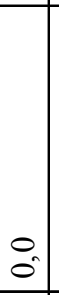 & ?. & $\overrightarrow{0}$ & $\begin{array}{l}0 \\
0\end{array}$ & 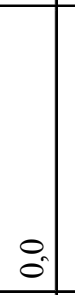 & 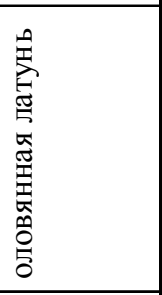 & 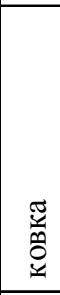 \\
\hline 50 & 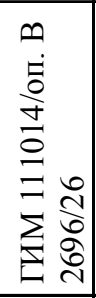 & 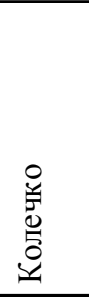 & 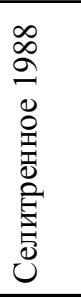 & 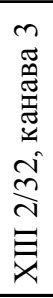 & $\overrightarrow{8}$ & $\begin{array}{l}0 \\
0\end{array}$ & î & $\begin{array}{l}0 \\
0\end{array}$ & $\vec{t}_{0}$ & $\stackrel{m}{=}$ & $\overrightarrow{0}$ & $\overrightarrow{0}$ & $\overrightarrow{0}$ & $\begin{array}{l}0 \\
0\end{array}$ & $\begin{array}{l}n \\
0\end{array}$ & 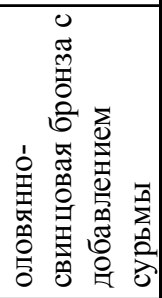 & 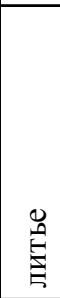 \\
\hline 51 & 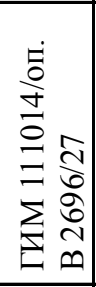 & 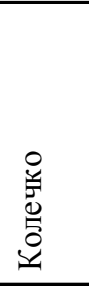 & $\begin{array}{l}\infty \\
\infty \\
0 \\
0 \\
0 \\
0 \\
\mathbb{1} \\
0 \\
0 \\
0 \\
0 \\
0 \\
0\end{array}$ & 亩 & $\hat{\varepsilon}$ & $\begin{array}{l}\infty \\
\dot{+}\end{array}$ & $\hat{\mathrm{i}}$ & $\overrightarrow{0}$ & $3^{m}$ & $\overrightarrow{0}$ & $\stackrel{t}{0}$ & 0 & $\overrightarrow{0}$ & 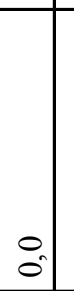 & $a^{n}$ & 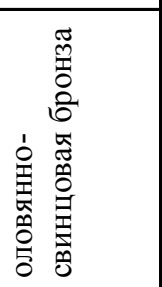 & $\begin{array}{l}0.0 \\
\stackrel{:}{E} \\
E\end{array}$ \\
\hline 52 & 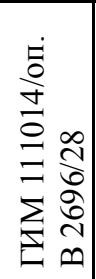 & 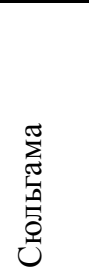 & 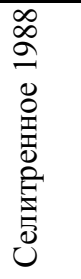 & 亩 & $\frac{\infty}{\sigma}$ & $\begin{array}{c}\infty \\
i\end{array}$ & $\stackrel{\sigma_{n}}{\rightarrow}$ & $\stackrel{0}{m}$ & $\tilde{o}$ & $\ddot{0}$ & $\overrightarrow{0}$ & ț & $\overrightarrow{0}$ & $\begin{array}{l}0 \\
0\end{array}$ & O & 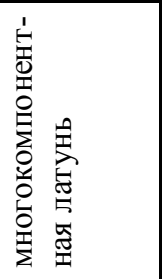 & $\begin{array}{l}\stackrel{0}{\Theta} \\
\stackrel{G}{G}\end{array}$ \\
\hline
\end{tabular}




\section{СИМВОЛИЗМ И ТЕХНОЛОГИИ В МАТЕРИАЛЬНОЙ КУЛЬТУРЕ}

Продолжение таблицы 1

Continuation of Table 1

\begin{tabular}{|c|c|c|c|c|c|c|c|c|c|c|c|c|c|c|c|c|c|c|}
\hline 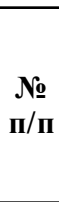 & 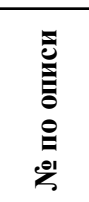 & 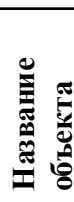 & 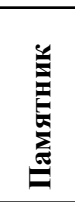 & 递 & E & ตี & बी & & 5 & $\sum_{4}^{\infty 00}$ & की & $\frac{\pi}{4}$ & I & $\ddot{z}$ & $\Xi$ & $\stackrel{00}{ \pm}$ & 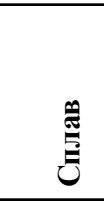 & : \\
\hline 53 & 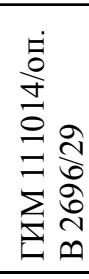 & 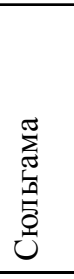 & 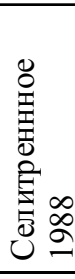 & 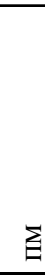 & ä & $\stackrel{\infty}{\sim}$ & $\alpha$ & & $i$ & $\overrightarrow{0}$ & $\overrightarrow{0}$ & $\tilde{c}$ & $\begin{array}{l}0 \\
0 \\
0\end{array}$ & $\overrightarrow{0}$ & $\stackrel{0}{0}$ & : & 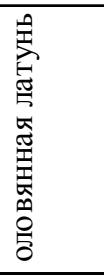 & 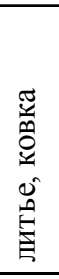 \\
\hline 54 & 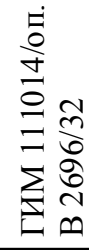 & 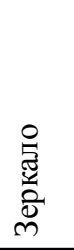 & 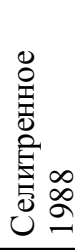 & 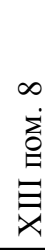 & $\stackrel{2}{\approx}$ & $\begin{array}{l}\text { in } \\
\text { na }\end{array}$ & ? & & $\begin{array}{c}0 . \\
-\end{array}$ & 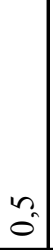 & 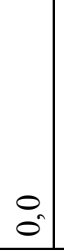 & $\overrightarrow{0}$ & $\stackrel{m}{0}$ & 0 & $\begin{array}{l}0 \\
0\end{array}$ & $\begin{array}{l}m \\
0\end{array}$ & 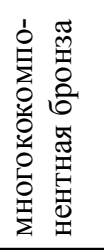 & $\begin{array}{l}0 \\
\stackrel{0}{\mid}\end{array}$ \\
\hline 55 & 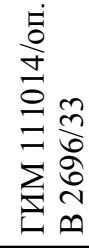 & 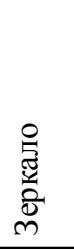 & 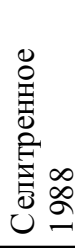 & 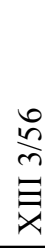 & छे & $\begin{array}{l}c \\
\hat{n}\end{array}$ & $\bar{c}$ & & $\begin{array}{l}n \\
v^{2}\end{array}$ & $\tilde{0}$ & $\overrightarrow{0}$ & $\tilde{o}^{1}$ & $\tilde{o}^{1}$ & $\begin{array}{ll}0 \\
8\end{array}$ & 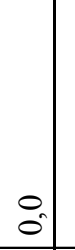 & $\begin{array}{l}0 \\
0\end{array}$ & 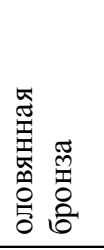 & 葛 \\
\hline 56 & 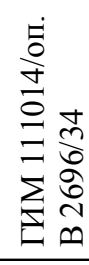 & 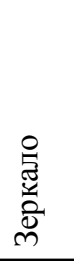 & 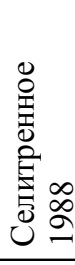 & 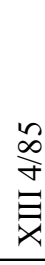 & $\stackrel{r}{r}$ & $\vec{J}$ & & & 3 & $\ddot{0}$ & $\overrightarrow{0}$ & 3 & $n$ & 0 & 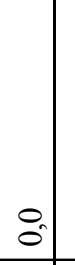 & $\begin{array}{l}0 \\
0\end{array}$ & 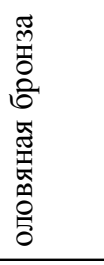 & $\begin{array}{l}0 \\
\stackrel{0}{E} \\
\stackrel{E}{E}\end{array}$ \\
\hline 57 & 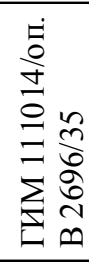 & 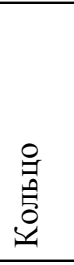 & 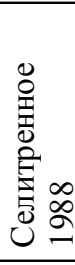 & 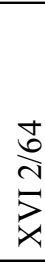 & $\stackrel{\text { an}}{\text { a }}$ & $\bar{c}$ & $y$ & & 8 & ?. & $\overrightarrow{0}$ & : & $\begin{array}{l}0 \\
0 \\
0\end{array}$ & 8 & $\begin{array}{l}0 \\
0\end{array}$ & $\overrightarrow{0}$ & 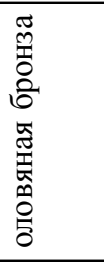 & 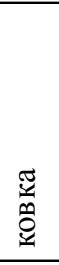 \\
\hline 58 & 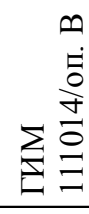 & 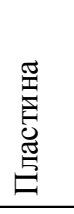 & 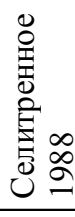 & 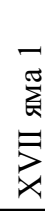 & $\begin{array}{l}0 \\
\infty \\
\infty\end{array}$ & 3 & $\exists$ & & B. & 3 & $\overrightarrow{0}$ & ת̊. & 3 & $\overrightarrow{0}$ & 8 & $\overrightarrow{0}$ & 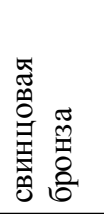 & 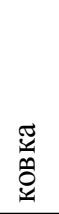 \\
\hline 59 & 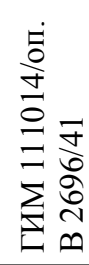 & 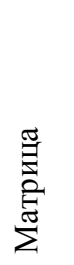 & 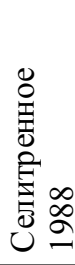 & $\underline{\xi}$ & 0 & $\begin{array}{r}+ \\
\sigma\end{array}$ & & & ? & $\overrightarrow{0}$ & $\because$ & $\ddot{0}$ & $\overrightarrow{0}$ & $\begin{array}{l}0 \\
0\end{array}$ & $\begin{array}{l}0 \\
0\end{array}$ & $\begin{array}{l}0 \\
0\end{array}$ & 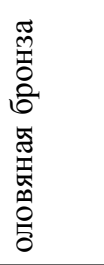 & 葛 \\
\hline
\end{tabular}


Окончание таблицы 1

End of Table 1

\begin{tabular}{|c|c|c|c|c|c|c|c|c|c|c|c|c|c|c|c|c|c|}
\hline $\begin{array}{l}\text { № } \\
\mathbf{\Pi 1} / \mathbf{I I}\end{array}$ & $\begin{array}{l}\vec{e} \\
\stackrel{\Xi}{0} \\
\stackrel{\Xi}{0} \\
\stackrel{01}{2}\end{array}$ & 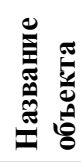 & 宸 & 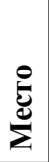 & $z$ & क & $\hat{2}$ & ง & $\frac{50}{4}$ & के & \& & 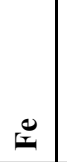 & $\bar{z}$ & $\xi$ & $\stackrel{\infty 00}{ \pm}$ & 总 & 胥 \\
\hline 60 & 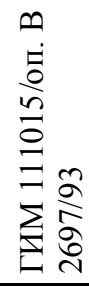 & 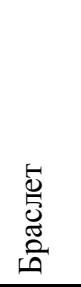 & 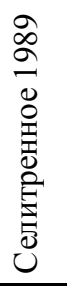 & & $\begin{array}{l}0 \\
\infty \\
\infty \\
\infty\end{array}$ & $\begin{array}{c}0 \\
m\end{array}$ & $\dot{\delta}$ & $\overrightarrow{0}$ & 今. & $\overrightarrow{0}$ & $\overrightarrow{0}$ & $\hat{0}$ & 8 & $\begin{array}{l}0 \\
0\end{array}$ & $\overrightarrow{0}$ & 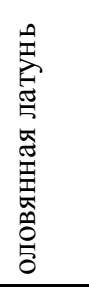 & 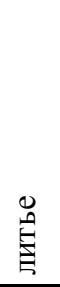 \\
\hline \multirow[t]{3}{*}{61} & \multirow{3}{*}{ 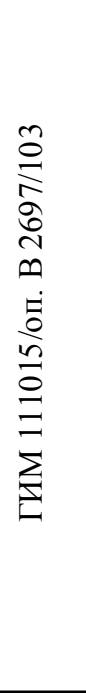 } & $\begin{array}{l}\text { 莺 } \\
\text { : } \\
\text { : }\end{array}$ & 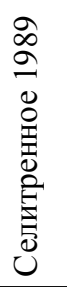 & $\underline{\xi}$ & $\begin{array}{l}\infty \\
2 \\
2\end{array}$ & $\overrightarrow{0}$ & $\begin{array}{l}2 \\
0\end{array}$ & $\dot{\sigma}_{0}$ & 0 & $\begin{array}{l}0 \\
0\end{array}$ & $\begin{array}{l}0 \\
0\end{array}$ & $\begin{array}{l}m \\
0\end{array}$ & $\overrightarrow{0}$ & $\begin{array}{l}0 \\
0\end{array}$ & $\begin{array}{l}0 \\
0\end{array}$ & 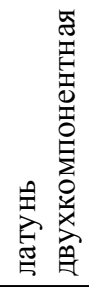 & 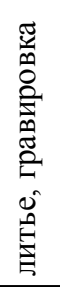 \\
\hline & & $\underset{\check{2}}{\stackrel{\pi}{2}}$ & & & $\begin{array}{l}\infty \\
\infty \\
\infty\end{array}$ & $\because$ & $\begin{array}{l}0 \\
0 \\
0\end{array}$ & $\begin{array}{l}n \\
0\end{array}$ & $\begin{array}{l}0 \\
0 \\
0\end{array}$ & $\begin{array}{l}0 \\
0\end{array}$ & 0 & $\overrightarrow{0}$ & $\begin{array}{l}0 \\
0\end{array}$ & $\begin{array}{l}0 \\
0 \\
0\end{array}$ & \begin{tabular}{l|}
0 \\
0
\end{tabular} & $\frac{\mathrm{A}}{\mathrm{O}}$ & $\begin{array}{l}\text { 足 } \\
\stackrel{\Delta}{\mid}\end{array}$ \\
\hline & & 㔽 & & & $\begin{array}{c}0 \\
i \\
\infty\end{array}$ & $\overrightarrow{0}$ & 3 & $\begin{array}{l}n \\
\cong \\
0\end{array}$ & $\hat{\sigma}$ & $\begin{array}{l}0 \\
0 \\
0\end{array}$ & $\begin{array}{l}0 \\
0\end{array}$ & ?ै- & $\overrightarrow{0}$ & $\begin{array}{l}0 \\
0 \\
\end{array}$ & $\begin{array}{l}0 \\
0 \\
\end{array}$ & 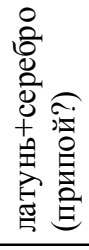 & \\
\hline 62 & 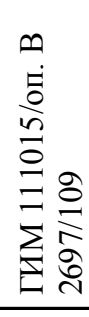 & 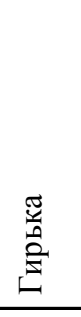 & 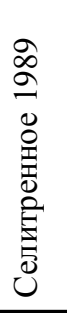 & 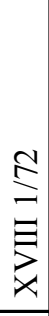 & $\begin{array}{l}\vec{j} \\
\infty\end{array}$ & $\begin{array}{l}\infty \\
\dot{+}\end{array}$ & $\hat{\infty}^{\circ}$ & \begin{tabular}{l}
0 \\
\multirow{+}{*}{}
\end{tabular} & $\overrightarrow{0}$ & $\overrightarrow{0}$ & 8 & $\overrightarrow{0}$ & 0 & 0 & $\overrightarrow{0}$ & 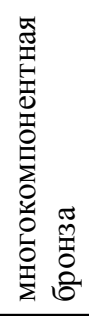 & $\begin{array}{l}\stackrel{0}{\circ} \\
\stackrel{5}{E}\end{array}$ \\
\hline 63 & 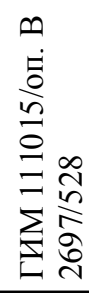 & 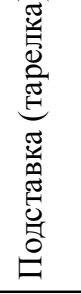 & 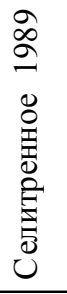 & 就 & $\overrightarrow{\hat{g}}$ & $\begin{array}{l}\infty \\
0 \\
0\end{array}$ & $\Rightarrow$ & $\begin{array}{c}+ \\
\dot{n}\end{array}$ & $\overrightarrow{0}$ & : & 今̂ & $\begin{array}{l}m \\
0\end{array}$ & $\begin{array}{l}1 \\
0\end{array}$ & $\begin{array}{l}0 \\
0 \\
0\end{array}$ & $\begin{array}{l}0 \\
0\end{array}$ & 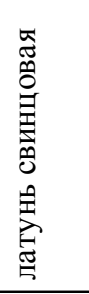 & $\begin{array}{l}0.0 \\
\stackrel{A}{E}\end{array}$ \\
\hline
\end{tabular}




\section{СИМВОЛИЗМ И ТЕХНОЛОГИИ В МАТЕРИАЛЬНОЙ КУЛЬТУРЕ}

\section{Таблица 2. Распределение проб по сплавам}

\section{Table 2. Alloy sample distribution}

\begin{tabular}{|l|l|r|r|}
\hline & \multicolumn{1}{|c|}{ Сплав } & \multicolumn{1}{|c|}{ Кол-во } & \multicolumn{1}{|c|}{$\%$} \\
\hline Латунь & двухкомпнентная $(\mathrm{Cu}+\mathrm{Zn})$ & 12 & 19,0 \\
\hline & оловянная $(\mathrm{Cu}+\mathrm{Zn}+\mathrm{Sn}, \mathrm{Zn}>\mathrm{Sn})$ & 8 & 12,7 \\
\hline & свинцовая $(\mathrm{Cu}+\mathrm{Zn}+\mathrm{Pb})$ & 2 & 3,2 \\
\hline & многокомпонентаная $(\mathrm{Cu}+\mathrm{Zn}+\mathrm{Sn}+\mathrm{Pb}, \mathrm{Zn}>\mathrm{Sn})$ & 7 & 11,1 \\
\hline Бронза & оловянная $(\mathrm{Cu}+\mathrm{Sn})$ & 4 & 6,3 \\
\hline & свинцовая $(\mathrm{Cu}+\mathrm{Pb})$ & 1 & 1,6 \\
\hline & свинцово-мышьяковистая $(\mathrm{Cu}+\mathrm{Pb}+\mathrm{As})$ & 4 & 1,6 \\
\hline & оловянно-свинцовая $(\mathrm{Cu}+\mathrm{Sn}+\mathrm{Sn})$ & 1 & 6,3 \\
\hline & оловянно-свинцовая с добавлением сурьмы $(\mathrm{Cu}+\mathrm{Sn}+\mathrm{Pb}+\mathrm{Sb})$ & 3 & 4,6 \\
\hline & оловянно-цинковая $(\mathrm{Cu}+\mathrm{Sn}+\mathrm{Zn}, \mathrm{Zn}<\mathrm{Sn})$ & 8 & 12,7 \\
\hline & многокомпонентная $(\mathrm{Cu}+\mathrm{Sn}+\mathrm{Pb}+\mathrm{Zn}, \mathrm{Zn}<\mathrm{Sn})$ & 5 & 7,9 \\
\hline & $\begin{array}{l}\text { многокомпонентная, с повышенным содержанием свинца } \\
\text { (Си+Sn+Рb+Zn, } \mathrm{Pb}>20 \%)\end{array}$ & 3 & 4,8 \\
\hline $\begin{array}{l}\text { Сплавы с } \\
\text { серебром }\end{array}$ & $\begin{array}{l}\text { многокомпонентный на основе меди, с повышенным } \\
\text { содержанием серебра }(\mathrm{Cu}+\mathrm{Sn}+\mathrm{Pb}+\mathrm{Zn}+\mathrm{Ag}, \mathrm{Ag}>20 \%)\end{array}$ & 3 & 4,8 \\
\hline & с золотом $(\mathrm{Au}+\mathrm{Ag}+\mathrm{Cu}, \mathrm{Au}>\mathrm{Ag}>\mathrm{Cu})$ & 1 & 1,6 \\
\hline & латунь с добавлением серебра $(\mathrm{Cu}+\mathrm{Zn}+\mathrm{Ag})$ & 63 &
\end{tabular}

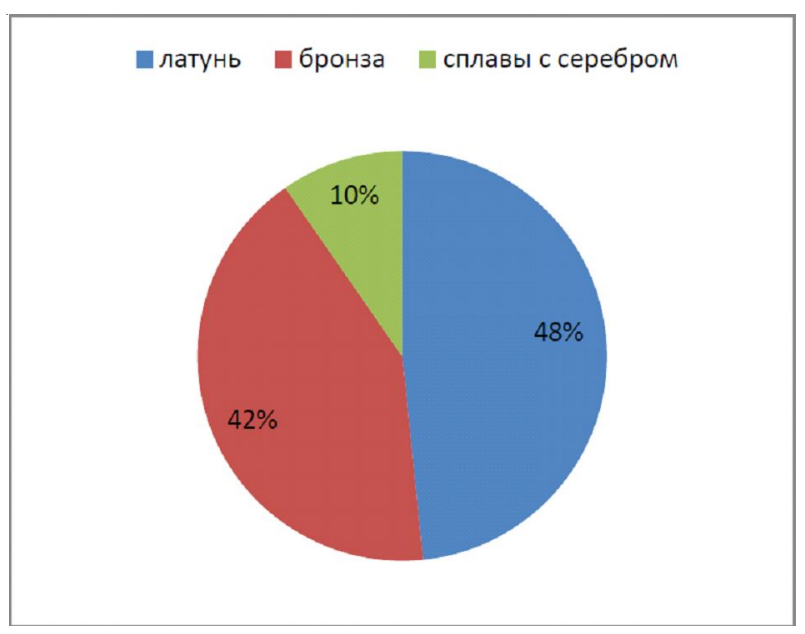

Соотношение основных типов сплавов

Ratio of the main types of alloys 


\section{СПИСОК ЛИТЕРАТУРЫ}

1. Барцева, Т. Б. Цветная металлообработка скифского времени. Лесостепное днепровское левобережье / Т. Б. Барцева. - М. : Наука, 1981. - 127 с.

2. Валиулина, С. И. Балынгузское (Торецкое) III селище и проблема преемственности городской культуры в округе Билярского городища в золотоордынский период / С. И. Валиулина // Татарская археология. - 2004. - № 1-2. - С. 12-13.

3. Дегтярева, А. Д. Методика поверхностного изучения цветного металла / А. Д. Дегтярева // Вестник археологии, антропологии и этнографии. - 2006. - № 6. - С. 117-126.

4. Ениосова, Н. В. Цветной металл Северо-Восточной Руси в IX-XV вв. / Н. В. Ениосова, Т. Г. Сарачева // Сельская Русь в IX-XIV вв. - М. : Наука, 2008. - C. 265-275.

5. Ениосова, Н. В. Ренгеноспектральный метод анализа археологического металла: преимущества, ограничения и ловушки в процессе измерения и интерпретации / Н. В. Ениосова, Р. А. Митоян // Труды IV (XX) Всероссийского археологического съезда в Казани. T. IV. - Казань : Отечество, 2014. -C. 143-146.

6. Ениосова, Н. В. Химический состав ювелирного сырья эпохи средневековья и пути его поступления на территорию Древней Руси / Н. В. Ениосова, Р. А. Митоян, Т. Г. Сарачева // Цветные и драгоценные металлы и их сплавы на территории Восточной Европы в эпоху Средневековья. - М. : Восточная литература, 2008. -С. 107-188.

7. Зайцева, И. Е. Цветной металл Волжской Болгарии (предварительный анализ) / И. Е. Зайцева // Русь и Восток в IX-XVI веках: новые археологические исследования. - М. : Наука, 2010. - С. 116-138.

8. Зеленцова, О.В.Поясной набор с позолотой из Крюковско-Кужновского могильника Средневековой мордвы / О.В.Зеленцова, Р. А. Митоян, И. А. Сапрыкина // Российская археология. -2012 . №2. - C. 52-61.

9. Ковалева, К. С. Вторичный металл в ремесленном производстве нижневолжских городов 3олотой Орды / К. С. Ковалева // Азак и мир вокруг него : материалы Междунар. науч. конф. (Азов, 14 18 окт. 2019 г.). - Азов : Из-во Азовского музея-заповедника, 2019. - С. 98-101.

10. Ковалева, К. С. Результаты исследования химического состава металла и техники изготовления изделий из цветных металлов из раскопок курганных групп Бахтияровка и Царевского городища / К. С. Ковалева // Новые материалы и методы археологического исследования. От критики источника к обобщению и интерпретации данных : материалы V Междунар. конф. молодых ученых. - М. : ИА PAH, 2019. - C. 242-244. - DOI: 10.25681/IARAS. 2019.978-5-94375-270-4.242-244.
11. Методы определения элементного состава металла археологических объектов при коррозионных наслоениях и в ограниченных условиях пробоотбора материала / А. Ю. Лобода, Е. Ю. Терещенко, А. В. Антипенко, В. М. Ретивов, М. Ю. Пресняков, Н. Н. Колобылина, О. А. Кондратьев, Н. И. Шишлина, Е. Б. Яцишина, П. К. Кашкаров // Поволжская археология. - 2018. - № 4 (26). - С. 203-221. - DOI: https://doi.org/10.24852/2018.4.26.203.221.

12. Недашковский, Л. Ф. Химический состав изделий из цветных металлов с золотоордынских поселений центральной части Саратовской области / Л. Ф. Недашковский // Нижневолжский археологический вестник. - 2002. - Вып. 5. - С. 335-347.

13. Недашковский, Л. Ф. Химический состав изделий из цветных металлов с золотоордынских поселений северных районов Нижнего Поволжья / Л. Ф. Недашковский // Stratum Plus. - 2018. - № 6. C. 243-254.

14. Равич, И. Г. Эталоны микроструктур оловянной бронзы / И. Г. Равич // Художественное наследие. -1983 -№ 8 (38). - С. 136-143.

15. Смирягин, А. П. Промышленные цветные металлы и сплавы / А. П. Смирягин, Н. А. Смирягина, А. В. Белова. - М. : Металлургия, 1974. -488 с.

16. Технология металлов / А. Н. Брюханов, В. Ю. Лахтин, А. И. Малышев, Г. Н. Николаев, Ю. А. Шувалов. - М. : Машгиз, 1959. -599 с.

17. Тишкин, А. А. Металлические зеркала как источник по древней и средневековой истории Алтая (по материалам музея археологии и этнографии Алтая Алтайского государственного университета) / А. А. Тишкин, Н. Н. Серегин. - Барнаул : Азбука, 2011.- 144 с.

18. Тишкин, А. А. Использование ренгенофюоресцентоного анализа в археологических исследованиях / А. А. Тишкин, С. В. Хаврин // Теория и практика археологических исследований. $-2006 .-$ Вып. 2. - С. 74-85.

19. Федоров-Давыдов, Г.А. Золотоордынские города Поволжья / Г.А. Федоров-Давыдов. - М. : Изд-во Моск. ун-та, 1994. - 232 с.

20. Хлебникова, Т. А. Анализы Болгарского цветного металла / Т. А. Хлебникова // Город Болгар: ремесло металлургов, кузнецов, литейщиков. - Казань : ИЯЛИ АН Татарстана, 1996. C. $258-279$.

21. Rehren, Th. Coins, Artefacts and Isotopes Archaeometallurgy and Archaeometry / Th. Rehren, E. Pernicka // Archaeometry. 50 ${ }^{\text {th }}$ Anniversary Issue. 2008. - Vol. 50, part 2. - P. 232-248.

22. Smith, D. Handheld X-Ray Fluorescence Analysis of Renaissance Bronzes: Practical Approches to Quantification and Acquistion / D. Smith // Hendheld XRF for Art and Arhaeology. - Leuven : Leuven University Press, 2008. - P. 37-74. 


\section{REFERENCES}

1. Bartseva T.B. Tsvetnaya metalloobrabotka skifskogo vremeni. Lesostepnoe dneprovskoe levoberezhye [Non-Ferrous Metalworking of the Scythian Time. Forest-Steppe Dnieper Left Bank]. Moscow, Nauka Publ., 1981. 127 p.

2. Valiulina S.I. Balynguzskoe (Toretskoe) III selishche i problema preemstvennosti gorodskoy kultury $\mathrm{v}$ okruge Bilyarskogo gorodishcha $\mathrm{v}$ zolotoordynskiy period [Balynguz (Toretsk) III Settlement and the Problem of the Continuity of Urban Culture in the District of Bilyar Settlement in the Golden Horde Period]. Tararskaya arkheologiya [Tatar Archaeology], 2004, no. 1-2, pp. 12-13.

3. Degtyareva A.D. Metodika poverkhnostnogo izucheniya tsvetnogo metalla [Method of Surface Study of Non-Ferrous Metal]. Vestnik arkheologii, antropologii i etnografii, 2006, no. 6, pp. 117-126.

4. Eniosova N.V., Saracheva T.G. Tsvetnoy metall Severo-Vostochnoy Rusi v IX/0XV vv. [Non-Ferrous Metal of North-Eastern Russia in the $9^{\text {th }}-$ $15^{\text {th }}$ Centuries]. Selskaya Rus v IX-XIV vv. [Rural Russia in the $9^{\text {th }}-14^{\text {th }}$ Centuries]. Moscow, Nauka Publ., 2008, pp. 265-275.

5. Eniosova N.V., Mitoyan R.A. Rengenospektralnyy metod analiza arheologicheskogo metalla: preimushchestva, ogranicheniya i lovushki v protsesse izmereniya i interpretatsii [X-ray Spectral Method of Analysis of Archaeological Metal: Advantages, Limitations and Traps in the Process of Measurement and Interpretation]. Trudy IV $(X X)$ Vserossiyskogo arkheologicheskogo syezda $v$ Kazani. T. IV [Proceedings of the $4^{\text {th }}\left(20^{\text {th }}\right)$ All-Russian Archaeological Congress in Kazan. Vol. IV]. Kazan, Otechestvo Publ., 2014, pp. 143-146.

6. Eniosova N.V., Mitoyan R.A., Saracheva T.G. Khimicheskiy sostav yuvelirnogo syrya epokhi srednevekovya i puti ego postupleniya na territoriyu Drevney Rusi [The Chemical Composition of Jewelry Raw Materials from the Middle Ages and Its Entry into the Territory of Ancient Russia]. Tsvetnye $i$ dragotsennye metally $i$ ikh splavy na territorii Vostochnoy Evropy v epokhu Srednevekovya [NonFerrous and Precious Metals and Their Alloys in Eastern Europe in the Middle Ages]. Moscow, Vostochnaya literatura Publ., 2008, pp. 107-188.

7. Zaytseva I.E. Tsvetnoy metall Volzhskoy Bolgarii (predvaritelnyy analiz) [Non-Ferrous Metal of Volga Bulgaria (Preliminary Analysis)]. Rus i Vostokv IX-XVI vekah: novye arkheologicheskie issledovaniya [Rus and the East in the $9^{\text {th }}-$ $16^{\text {th }}$ Centuries: New Archaeological Research]. Moscow, Nauka Publ., 2010, pp. 116-138.

8. Zelentsova O.V., Mitoyan R.A., Saprykina I.A. Poyasnoy nabor s pozolotoy iz Kryukovsko-
Kuzhnovskogo mogilnika Srednevekovoy mordvy [Gilt Belt Set from Kruykovsko-Kuzhnovsky Cemetery of the Medieval Mordva]. Rossiyskaya arkheologiya [Russian Archaeology], 2012, no. 2, pp. 52-61.

9. Kovaleva K.S. Vtorichnyy metall v remeslennom proizvodstve nizhnevolzhskikh gorodov Zolotoy Ordy [Recycled Metal in the Craft Industry of the Lower Volga Cities of the Golden Horde]. Azak $i$ mir vokrug nego: materialy Mezhdunar. nauch. konf. (Azov, 14-18 oktyabrya 2019 g.) [Azak and the World Around Him. Proceedings of the International Scientific Conference (Azov, October 14-18, 2019)]. Azov, Izd-vo Azovskogo muzeya-zapovednika, 2019, pp. 98-101.

10. Kovaleva K.S. Rezultaty issledovaniya khimicheskogo sostava metalla i tekhniki izgotovleniya izdeliy iz tsvetnykh metallov iz raskopok kurgannykh grupp Bakhtiyarovka i Tsarevskogo gorodishcha [The Results of the Study of the Chemical Composition of Metal and the Manufacture of Non-Ferrous Metal Products from the Excavations of the Kurgan Groups of Bakhtiyarovka and Tsarevskoe Settlement]. Novye materialy $i$ metody arkheologicheskogo issledovaniya. Ot kritiki istochnika k obobshcheniyu $i$ interpretatsii dannykh: materialy V Mezhdunar. konf. molodykh uchenykh [New Materials and Methods of Archaeological Research. From Criticism of the Source to Generalization and Interpretation of Data. Materials of the $5^{\text {th }}$ International Conference of Young Scientists]. Moscow, IA RAN, 2019, pp. 242-244. DOI: 10.25681/IARAS.2019.978-5-94375-270-4.242-244.

11. Loboda A.Yu., Tereshchenko E.Yu., Antipenko A.V., Retivov V.M., Presniakov M.Yu., Kolobylina N.N., Kondratiev O.A., Shishlina N.I., Yatsishina E.B., Kashkarov P.K. Metody opredeleniya elementnogo sostava metalla arkheologicheskikh obyektov pri korrozionnykh nasloeniyakh i v ogranichennykh usloviyakh probootbora materiala [Local and Integral Techniques in Metal Compositional Analysis of Archaeological Objects with Surface Corrosion Layers and Small Sample Quantities]. Povolzhskaya arkheologiya [The Volga River Region Archaeology], 2018, vol. 4(26), pp. 203-221. DOI: https:// doi.org/10.24852/2018.4.26.203.221.

12. Nedashkovsky L.F. Khimicheskiy sostav izdeliy iz tsvetnykh metallov s zolotoordynskikh poseleniy tsentralnoy chasti Saratovskoy oblasti [Chemical Composition of Non-Ferrous Articles from the Golden Horde Settlements of the Central Part of Saratov Region]. Nizhnevolzhskiy arkheologicheskiy vestnik [The Lower Volga Archaeological Bulletin], 2002, iss. 5, pp. 335-347.

13. Nedashkovsky L.F. Khimicheskiy sostav izdeliy iz tsvetnykh metallov s zolotoordynskikh poseleniy severnykh rayonov Nizhnego Povolzhya [Chemical Composition of Non-Ferrous Artifacts from 
the Golden Horde Settlements of the Northern Areas of the Lower Volga Region]. Stratum Plus, 2018, no. 6, pp. 243-254.

14. Ravich I.G. Etalony mikrostruktur olovyannoy bronzy [Tin Bronze Microstructure Standards]. Khudozhestvennoe nasledie [Artistic Heritage], 1983, no. 8 (38), pp. 136-143.

15. Smiryagin A.P., Smiryagina N.A., Belova A.V. Promyshlennye tsvetnye metally $i$ splavy [Industrial Non-Ferrous Metals and Alloys]. Moscow, Metallurgiya Publ., 1974. 488 p.

16. Bryukhanov A.N., Lakhtin V.Yu., Malyshev A.I., Nikolaev G.N., Shuvalov Yu.A. Tekhnologiya metallov [Technology of Metal]. Moscow, Mashgiz Publ., 1959. 599 p.

17. Tishkin A.A., Seregin N.N. Metallicheskie zerkala kak istochnik po drevney i srednevekovoy istorii Altaya (po materialam muzeya arkheologii $i$ etnografii Altaya Altayskogo gosudarstvennogo universiteta) [Metal Mirrors as a Source on the Ancient and Medieval History of Altai (Based on Materials from the Museum of Archeology and Ethnography of Altai, Altai State University)]. Barnaul, Azbuka Publ., 2011. 144 p.
18. Tishkin A.A., Havrin S.V. Ispolzovanie rengenofyuorestsentonogo analiza $\mathrm{v}$ arkheologicheskikh issledovaniyakh [The Use of X-Ray Analysis in Archaeological Research]. Teoriya $i$ praktika arkheologicheskikh issledovaniy [Theory and Practice of Archaeological Research], 2006, iss. 2, pp. 74-85.

19. Fedorov-Davydov G.A. Zolotoordynskie goroda Povolzhya [The Golden Horde Cities of the Volga Region]. Moscow, Izd-vo Moskovskogoun-ta, 1994.232 p.

20. Khlebnikova T.A. Analizy Bolgarskogo tsvetnogo metalla [Analyzes of Bulgarian Non-Ferrous Metal]. Gorod Bolgar: remeslo metallurgov, kuznetsov, liteyshchikov [City of Bolgar: Craft of Metallurgists, Blacksmiths, Casters]. Kazan, IYALI AN Tatarstana, 1996, pp. 258-279.

21. Rehren Th., Pernicka E. Coins, Artefacts and Isotopes - Archaeometallurgy and Archaeometry. Archaeometry. 50 th Anniversary Issue, 2008, vol. 50, part 2, pp. 232-248.

22. Smith D. Handheld X-Ray Fluorescence Analysis of Renaissance Bronzes: Practical Approches to Quantification and Acquistion. Hendheld XRF for Art and Arhaeology. Leuven, Leuven University Press, 2008, pp. 37-74.

\section{Information About the Author}

Kseniya S. Kovaleva, Postgraduate Student, Institute of Archaeology RAS, Dm. Ulyanova St, 19, 117036 Moscow, Russian Federation; Laboratory Assistant, Laboratory of Archaeological Research, Volgograd State University, Prosp. Universitetsky, 100, 400062 Volgograd, Russian Federation, ksenmorgan@gmail.com, kovaleva@volsu.ru,https://orcid.org/0000-0002-5429-1072

\section{Информация об авторе}

Ксения Сергеевна Ковалева, аспирант, Институт археологии РАН, ул. Дм. Ульянова, 19, 117036 г. Москва, Российская Федерация; лаборант лаборатории археологических исследований, Волгоградский государственный университет, просп. Университетский, 100, 400062, г. Волгоград, Российская Федерация, ksenmorgan@gmail.com, kovaleva@volsu.ru, https://orcid.org/0000-0002-5429-1072 